\title{
The role of money in monetary policymaking ${ }^{1}$
}

\author{
Klaus Masuch, Sergio Nicoletti-Altimari and Massimo Rostagno, ${ }^{2}$ \\ European Central Bank; \\ Huw Pill, ${ }^{3}$ Harvard University
}

\begin{abstract}
In this paper, the conceptual and empirical bases for the role of monetary aggregates in monetary policy making are reviewed. It is argued that money can act as a useful information variable in a world in which a number of indicators are imperfectly observed. In this context, the paper discusses the role of a reference value or benchmark for money growth in episodes of heightened financial uncertainty. A reference value for money growth can also act as an anchor for expectations and policy decisions to prevent divergent dynamics, such as the spiralling of the economy into a liquidity trap, which can occur under simple interest rate rules for policy conduct. The paper concludes that using information included in monetary aggregates in monetary policy decisions can provide an important safeguard against major policy mistakes in the presence of model uncertainty.
\end{abstract}

\section{Introduction}

Inflation is a monetary phenomenon. Monetary growth in excess of increases in the public's demand for money balances will eventually decrease the purchasing power of money or, equivalently, raise the general price level. The long-term relationship between money and prices has been a cornerstone of monetary economics for several centuries (eg Hume (1752)) and has been documented for many countries and many eras (eg McCandless and Weber (1995)).

While recognition of this empirical regularity is almost ubiquitous within the economics profession, substantial controversy persists about the usefulness of the relationship between money and prices in understanding, predicting and controlling inflation, and thus about its relevance for the design and implementation of monetary policy. Such controversy continues to be reflected in the ongoing debate about the appropriate design of monetary policy strategies.

Following the unacceptably high rates of inflation observed during the 1970s, many leading central banks adopted intermediate targets for monetary growth as the centrepiece of their monetary policy strategies. However, in the more benign inflationary environment of the 1990s, the role played by monetary aggregates in the policy framework of many central banks diminished. By the end of the century, Laurence Meyer (2001), a member of the Federal Reserve System's Board of Governors, was able to assert "... money plays no role in today's consensus macro model, and it plays virtually no role in the conduct of monetary policy, at least in the United States." Nonetheless, other central banks give monetary analysis a much more important role in their formulation of monetary policy. Notably, the European Central Bank (ECB) has accorded "a prominent role to money" within its monetary policy strategy (ECB (1999a,b), Issing et al (2001)).

An earlier version of this paper was presented at the AEA meetings in Atlanta, 4-6 January 2002. We are grateful to C Brand, D Gerdesmeier, V Gaspar, M Goodfriend, H-J Klöckers, G Korteweg, R Motto, P Moutot and C Willeke for very helpful comments. The views expressed in this paper are those of the authors and do not necessarily reflect those of either the European Central Bank or the Eurosystem.

2 Monetary Policy Strategy Division, Directorate Monetary Policy, European Central Bank, D-60666 Frankfurt, Germany. Tel: +49 691344 0. E-mail: massimo.rostagno@ecb.int.

3 Morgan 279, Harvard Business School, Boston, MA 02163, United States of America. Tel: +1 617 495-6788. E-mail: hpill@hbs.edu. 
To the casual observer, the suggestion that monetary developments are not an important component of monetary policymaking sounds odd. As reflected in ECB (2000), Selody (2001) and King (2002), central banks generally adopt the view that monetary developments should not be ignored since - at a minimum - they offer an additional source of information which can help improve the robustness of monetary policy decisions (see Pill (2001)). This notwithstanding, much - although not all - recent academic discussion of monetary policy has neglected or ignored monetary aggregates. ${ }^{4}$ This contrasts with the seminal work of monetarist economists such as Milton Friedman, who saw monetary dynamics as central to understanding the inflation process (eg Friedman and Schwartz (1963)). In the light of the contrast between these two branches of the literature, the prominent role of money in the ECB's monetary policy strategy ${ }^{5}$ has been the subject of an ongoing debate in both academic and policy circles.

Against the background of a more general discussion of the role of money and monetary analysis in monetary policymaking, this paper discusses conceptual and empirical aspects of the role of money in the conduct of monetary policy. Three related aspects - which are not mutually inconsistent - of the role of money in monetary policymaking can be distinguished.

First, monetary aggregates might be useful to proxy for variables that are unobservable or observable only with time lags. Thereby money can contribute information for assessing the appropriate stance of monetary policy, which is not included in simple interest rate rules. A simple comparison between the short term rate manoeuvred by the central bank and some conventional interest rate benchmark, say based on a Taylor rule, may often be a very inaccurate measure of the prevailing monetary conditions as perceived by market participants. There are at least two dimensions to this signalling and proxying role of money. One such dimension is related to the fact that the construction of summary indicators for economic slack or overheating is subject to considerable dispute. Therefore, policymakers' knowledge of the output gap may not at all be superior to their knowledge of money velocity behaviour, and so they may find it useful to consult money growth data as an early indicator of the prevailing economic conditions. Another aspect of money as an incremental gauge of the posture of policy becomes apparent in times of financial turbulence.

Second, and related to the above discussion, money may play an important structural role in the transmission mechanism of monetary policy to the price level. The importance of such transmission channels is essentially an empirical question, and may vary over time or even prove to be episodic. As discussed by King (2002), money and credit would play an important role if imperfections in the financial sector (ie borrowing and liquidity constraints) permit changes in the structure of balance sheets to influence yields and spreads in a manner that is relevant for intertemporal economic behaviour, such as pricing, consumption, saving and investment decisions. ${ }^{6}$ Should such effects prove important, neglecting monetary dynamics in the formulation of monetary policy decisions will come at a potentially large cost. Some commentators cite the recent prolonged Japanese recession as an example of such costs, on the basis that asset market dynamics in Japan were driven or accommodated by a monetary policy that neglected monetary and financial developments.

Finally, money can provide a nominal anchor for the economy. A monetary policy that responds to monetary developments - in addition to the fundamental shocks which hit the economy from time to time - can help to rule out destabilising explosive paths for inflation expectations that could be triggered and sustained by self-fulfilling expectations.

Of course, experience in the conduct of monetary policy over many decades has demonstrated that reliable guideposts come and go, sometimes requiring policymakers to review and adjust their

\footnotetext{
Analyses conducted in the context of strategies based on inflation targeting or Taylor rules are illustrative of this approach.

5 The reference value and monetary analysis more generally form the money pillar of the ECB's strategy (ECB (1999a, 2000)). The ECB points out that monetary analysis and the respective models have always to be seen in conjunction with the second pillar of the ECB's monetary policy strategy, which uses the analysis of other economic and financial indicators and models for the support of monetary policy decisions. Much of the academic criticism of the ECB's assignment of a prominent role has arisen in the context of the so-called "new neoclassical synthesis" view of the macroeconomy (Goodfriend and King (1997)). In this context, monetary aggregates are not seen as playing an active role in the transmission mechanism of monetary policy and, as such, should not play an important role - still less a "prominent role" - in the formulation of monetary policy decisions.

6 Note that that situation constitutes a violation of the Modigliani/Miller theorem, which states that the financial structure of a firm or household should not affect its value and thus its economic decisions and behaviour.
} 
theories, procedures and operating methods. This notwithstanding, there are many reasons why the role of money in monetary policymaking has proved durable. The remainder of the paper, in reviewing these reasons, is organised as follows.

Section 2 surveys the empirical properties of money, focusing on results for the euro area. While much of the evidence relates to the indicator properties of monetary dynamics for inflation (rather than investigating structural models of the transmission mechanism), this section nevertheless offers broad empirical support for the incorporation of monetary analysis into the monetary policymaking process.

Section 3 reviews a number of conceptual arguments in favour of assigning a prominent role to money in the formulation of monetary policy. In large part, these arguments follow from the view that money provides a nominal anchor to the economy, which helps avoid instability in the economy by ruling out indeterminacy or ambiguity in the determination of the price level.

Section 4 discusses how monetary analysis can be combined with analysis of demand and supply interactions and cost pressures to arrive at a single policy decision regarding the level of short-term interest rates. This discussion takes as its starting point uncertainty about the role of money in the transmission mechanism of monetary policy. A well designed monetary policy should acknowledge this uncertainty, but nevertheless ensure that monetary developments are not ignored or neglected in the design of policy decisions.

While this paper cannot (and does not attempt to) resolve all issues related to the role of monetary developments in formulating monetary policy, it does provide empirical, conceptual and practical support for assigning money an important role in monetary policy decisions in the euro area. These are summarised briefly in Section 5, which offers some brief concluding remarks.

\section{Empirical foundations}

Since the ECB and the single monetary policy have been assigned the primary objective of maintaining price stability in the euro area, monetary developments should only influence monetary policy decisions insofar as they provide information that furthers the achievement of that objective. In other words, monetary developments are important for monetary policy decisions to the extent that they cause, help to predict or are otherwise associated with price developments such that they should play a role in monetary policy decisions.

Ideally, the relationship between monetary and price developments would be explored in the context of a structural model with well developed micro-foundations. Unfortunately, notwithstanding ensuing discussion, structural models of monetary and financial interactions that are both sufficiently empirically relevant and conceptually appealing to be used as a guide to monetary policy decisions have yet to be developed. While considerable progress is being made in the field of monetary dynamic general equilibrium (DGE) models, their practical relevance for policymaking awaits further tests.

Consequently, in practice, empirical assessments of the relationship between money and prices are based on semi-structural or reduced-form models such as money demand equations, VARs or reduced-form indicator relationships. The remainder of this section reviews the application of such approaches to euro area data.

\section{(a) Stability of the relationship between money and prices}

The stability of the relationship between the money stock and the price level is typically evaluated in the context of a money demand equation, which relates money to prices and other key macroeconomic variables (such as real income and interest rates). Stability is assessed using cointegration techniques (Engle and Granger (1987), Johansen and Juselius (1990)), which test whether a stable long-run relationship among the levels of the variables exists.

A number of such studies have been undertaken on euro area data. Since cointegration techniques require long data samples, these investigations rely largely on data for the euro area prior to monetary 
union constructed from pre-existing national monetary series. In addition to the usual concerns regarding the stability of economic relationships in the face of a regime change such as the introduction of the single monetary policy, the empirical analysis thus faces additional, though unavoidable, uncertainties regarding the quality of the data and the appropriate aggregation technique.

\section{Table 1}

\section{Summary of studies of the long-run money demand equations for euro area M3}

\begin{tabular}{|c|c|c|c|c|c|c|}
\hline & Sample & $\begin{array}{l}\text { Aggregation } \\
\text { method }\end{array}$ & $\begin{array}{l}\text { Income } \\
\text { elasticity }\end{array}$ & $\begin{array}{l}\text { Interest rate } \\
\text { (semi) elasticity }\end{array}$ & $\begin{array}{l}\text { Other variables } \\
\text { in long-run } \\
\text { money demand } \\
\text { equation }\end{array}$ & $\begin{array}{c}\text { Weak } \\
\text { exogeneity }\end{array}$ \\
\hline $\begin{array}{l}\text { Coenen } \\
\text { and } \\
\text { Vega } \\
(1999)\end{array}$ & $\begin{array}{l}1980: 4- \\
1997: 2\end{array}$ & $\begin{array}{l}\text { Sum logs of } \\
\text { national } \\
\text { components }\end{array}$ & 1.14 & $\begin{array}{l}-0.820 \\
\text { (on the spread } \\
\text { between the long- } \\
\text { and short-term } \\
\text { interest rate) }\end{array}$ & $\begin{array}{l}\text { Inflation, with a } \\
\text { coefficient of } \\
-1.462 \\
\text { (interpreted as a } \\
\text { measure of } \\
\text { opportunity cost) }\end{array}$ & $\begin{array}{l}\text { Output, } \\
\text { inflation, } \\
\text { short-term } \\
\text { interest rate, } \\
\text { long-term } \\
\text { interest rate }\end{array}$ \\
\hline $\begin{array}{l}\text { Brand } \\
\text { and } \\
\text { Cassola } \\
(2000)\end{array}$ & $\begin{array}{l}\text { 1980:1- } \\
\text { 1999:3 }\end{array}$ & $\begin{array}{l}\text { Sum national } \\
\text { components at } \\
\text { irrevocable fixed } \\
\text { exchange rates }\end{array}$ & 1.33 & $\begin{array}{l}-1.608 \\
\text { (on the long-term } \\
\text { interest rate) }\end{array}$ & $\begin{array}{l}\text { None } \\
\text { (estimated as a } \\
\text { system with the } \\
\text { yield curve and } \\
\text { Fischer parity } \\
\text { conditions) }\end{array}$ & None \\
\hline $\begin{array}{l}\text { Calza } \\
\text { et al } \\
(2001)\end{array}$ & $\begin{array}{l}\text { 1980:1- } \\
\text { 1999:4 }\end{array}$ & $\begin{array}{l}\text { Sum national } \\
\text { components at } \\
\text { irrevocable fixed } \\
\text { exchange rates }\end{array}$ & 1.34 & $\begin{array}{l}-0.86 \\
\text { (on the spread } \\
\text { between the short- } \\
\text { term market interest } \\
\text { rate and the own } \\
\text { rate on } \mathrm{M} 3 \text { ) }\end{array}$ & None & Output \\
\hline
\end{tabular}

Sources: Coenen and Vega (1999); Brand and Cassola (2000); Calza et al (2001).

Three major studies of the demand for the broad monetary aggregate $\mathrm{M} 3$ in the euro area have been prepared and published by ECB staff (Coenen and Vega (1999), Brand and Cassola (2000), Calza et al (2001)). ${ }^{8}$ The main results of these papers are summarised in Table 1 . While the approaches vary in detail, ${ }^{9}$ all three studies find a stable long-run demand for euro area $\mathrm{M} 3$, ie a cointegrating relationship involving money, the price level, national income and some opportunity cost variables is obtained. ${ }^{10}$ The intuition behind this finding is powerfully illustrated in Graph 1, which shows the income velocity of circulation for euro area M3 in the period 1980-2001. The steady and smooth decline in M3 velocity over this period reflects the stability of the estimated money demand equations.

7 However, these concerns apply to all data series for the euro area in the period prior to the introduction of the euro. In practice, the quality of the monetary data is thought to be at least as high as that of other series.

8 Euro area M3 is defined as the following liabilities of euro area monetary financial institutions (MFIs) held by euro area residents: currency in circulation; overnight deposits; deposits with agreed maturity up to three years; deposits redeemable at notice up to three months; repurchase agreements; money market fund shares/units and money market paper; and debt securities with maturity up to two years.

9 Such as in the choice of interest rates used to measure the opportunity cost of holding money, in the aggregation technique used to construct the euro area back data, in the sample period investigated or in the specification of the equation.

10 More recent stability tests have confirmed the long-run stability conditions of the demand for M3 in the euro area. See, among others, Brand et al (2002) and Bruggeman et al (2003). 


\section{Graph 1}

M3 velocity trends for the euro area (log levels)

$$
\begin{array}{lll}
\text { - actual velocity } & \text {-.. } & \text { velocity trend } 1992-2002 \\
\text { velocity trend } 1980-2002 & &
\end{array}
$$

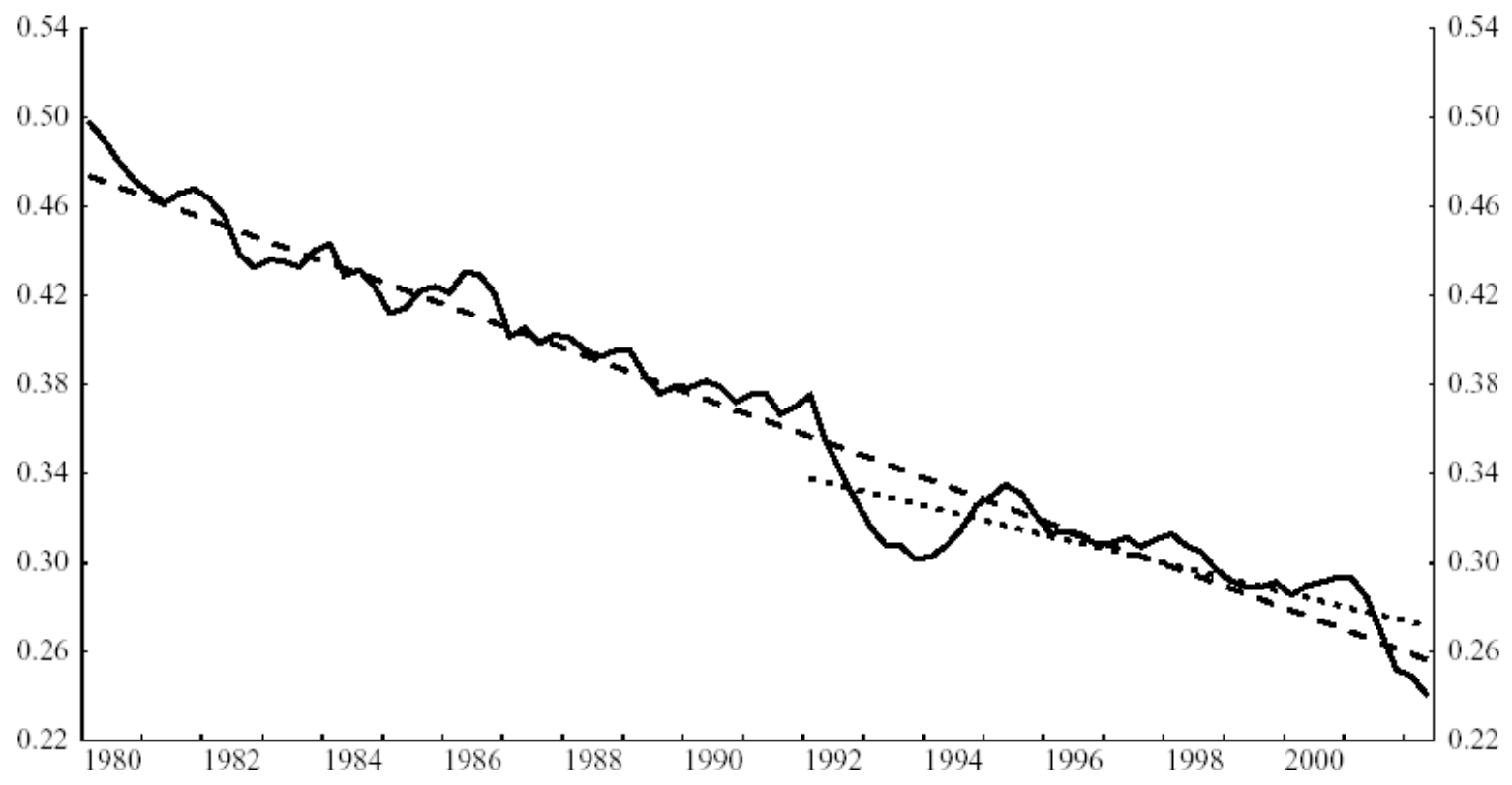

Note: Velocity is measured as the ratio of nominal GDP to M3. The underlying quarterly series are seasonally adjusted and constructed by aggregating national data converted into euros at the irrevocable exchange rates applied as from 1 January 1999 and as from 1 January 2001 in the case of Greece. The M3 series is based on the headline index of adjusted stocks (for further details, see the technical notes in the "Euro area statistics" section of the ECB Monthly Bulletin). M3 quarterly data are averages of end-month observations.

Source: ECB (M3) and ECB calculations based on Eurostat data (GDP).

Therefore, in contrast to some results obtained in other G7 economies (such as the United Kingdom and the United States), the evidence in favour of a simple and stable long-run relationship between broad money and the price level in the euro area over the last two decades appears robust. ${ }^{11}$

Stracca (2001) has also investigated the properties of a Divisia monetary aggregate for the euro area. Divisia aggregates weight the different components of monetary aggregates according to their "moneyness", with the weights being related to the opportunity cost associated with holding the monetary asset rather than a non-monetary asset bearing a market return. Stracca finds a stable demand for a euro area Divisia monetary aggregate, thereby demonstrating the robustness of the results outlined above to different aggregation techniques.

All in all, the stability of euro area money demand relationships suggests that a path for the evolution of the money stock can be derived which, conditional on developments in other macroeconomic variables, is consistent with the maintenance of price stability over the medium term.

\footnotetext{
These results support the a priori intuition that the demand for broader monetary aggregates is more likely to be stable than that for narrow monetary aggregates, since the former internalise the substitution between different categories of monetary asset that may create instabilities in the latter. This notwithstanding, money demand equations for euro area M1 also show surprising stability, albeit with less conventional specifications. Stracca (2000) investigates various specifications for the opportunity cost term and finds that a stable demand for $\mathrm{M} 1$ can be estimated if the interest rate semi-elasticity is allowed to vary with the level of interest rates.
} 


\section{Leading indicator properties of money for price developments and macroeconomic outcomes}

Given the lags in monetary transmission, a monetary policy aimed at the maintenance of price stability must be forward-looking. Leading information on future price developments is therefore crucial. Current monetary developments may contain information about future price developments, ie money may be a leading indicator of inflationary or deflationary pressures. It is important that such forwardlooking information is incorporated into the monetary policymaking process.

Money may also contain leading information on other macroeconomic variables that - although not constituting the ultimate objective of monetary policy - will influence the future course of the economy and, eventually, price developments. Such information is also central to monetary policy decisions, since it will influence the magnitude and timing of policy actions.

Several studies by the staff of the ECB have investigated the leading indicator properties of monetary developments in the euro area. For example, in the context of the money demand studies reported above, Brand and Cassola (2000) find that neither inflation nor aggregate demand are weakly exogenous to their money demand system, suggesting that monetary developments will help to predict these variables. Trecroci and Vega (2000) extend the Coenen-Vega money demand framework and also find that money helps predict future inflation. ${ }^{12}$ Broadly speaking, these results are consistent with those reported by Gerlach and Svensson (2002) for euro area M3. In the context of a $P^{*}$ model (Hallman et al (1991)), Gerlach and Svensson show that the so-called real money gap - a measure of the monetary disequilibrium relative to a stable long-run money demand equation - helps to predict future price developments.

A comprehensive assessment of the leading indicator properties of money in the euro area is offered by Nicoletti-Altimari (2001). Following the approach proposed by Stock and Watson (1999) for forecasting inflation in the United States, this study focuses on the out-of-sample forecasting performance of potential indicator variables.

A brief summary of the main results from this paper is presented in Table 2. The numbers in the table show the ratio of the forecast errors of a specific indicator model relative to those of a benchmark model, which captures inflation as a pure autoregressive process. A number greater than one therefore indicates a poor model, while a number less than one is associated with a model that performs better than the benchmark.

Using Table 2 (and, more generally, Nicoletti-Altimari's (2001) results), a number of conclusions can be drawn. First, there is considerable evidence that including monetary indicators improves the out-ofsample forecasting performance of a pure autoregressive model of price developments. Second, the performance of money-based indicators relative to other indicators (such as estimates of the output gap or cost pressures) improves as the horizon of the forecast lengthens. Third, it is noteworthy that (nominal) M3 growth offers the best relative forecast performance at the longest (three-year-ahead) horizon. Finally, various other monetary indicators - including measures of monetary growth, estimates of monetary disequilibrium (like the $P^{*}$ indicator) and indicators based on the components (eg M1, M2) and counterparts (notably loans to the private sector) of the broad monetary aggregate M3 - also appear to exhibit leading indicator properties for price developments. As a result, a composite monetary indicator which combines information from all these measures could be constructed which would outperform any individual measure. ${ }^{13}$

These results point to monetary developments being an important indicator of medium-term trends in price dynamics in the euro area. Given the necessarily medium-term orientation of monetary policy, ${ }^{14}$ they suggest that monetary indicators should be given an important role. On the basis of the indicator results, one can construct money-based forecasts of future price developments. Although, as with any single forecast, these money-based projections do not provide a sufficient basis for monetary policy

12 For a review of the monetary tools used at the ECB, see ECB (2001a) and Masuch et al (2001).

13 Very favourable leading indicator properties of broad monetary aggregates for inflation developments at medium-term horizons in the euro area are also found by Gottschalk et al (1999) and Cristadoro et al (2001).

14 Implied by Friedman's famous "long and variable lags" in the transmission mechanism of monetary policy actions to the price level. 
decisions ${ }^{15}$ such information can be an important input to the monetary policy process, eg for crosschecking results obtained on the basis of structural macroeconometric models.

Table 2

\section{Leading indicator of properties of monetary variables for HICP inflation in the euro area}

The sample period is 1992:1-2000:3

\begin{tabular}{|c|c|c|c|c|c|c|}
\hline & \multirow{2}{*}{ Variable } & \multirow{2}{*}{ Transformation } & \multicolumn{4}{|c|}{ Horizon in quarters } \\
\hline & & & 1 & 4 & 8 & 12 \\
\hline \multicolumn{2}{|c|}{$\begin{array}{l}\text { Univariate model, for reference } \\
\text { (\% RMSE) }\end{array}$} & & 0.50 & 0.62 & 0.70 & 1.02 \\
\hline \multicolumn{2}{|l|}{ M1 } & DLN & 0.98 & 1.04 & 1.05 & 0.95 \\
\hline \multicolumn{2}{|l|}{ M2 } & DLN & 0.98 & 0.92 & 0.89 & 0.90 \\
\hline \multicolumn{2}{|l|}{ M3 } & DLN & 0.90 & 1.29 & 0.98 & 0.43 \\
\hline \multicolumn{2}{|l|}{ Credit } & DLN & 0.93 & 0.90 & 0.74 & 0.58 \\
\hline \multirow[t]{2}{*}{ Money gap } & $\mathrm{BC}$ & LN & 1.05 & 1.02 & 0.87 & 0.64 \\
\hline & CV & LN & 1.11 & 1.05 & 1.31 & 1.46 \\
\hline \multirow[t]{2}{*}{$P^{*}$} & $B C$ & DLN & 0.86 & 0.76 & 0.60 & 0.80 \\
\hline & CV & DLN & 1.08 & 0.98 & 0.97 & 1.08 \\
\hline \multicolumn{2}{|l|}{ Output gap } & LN & 1.14 & 1.01 & 0.96 & 0.78 \\
\hline \multicolumn{2}{|c|}{ Unemployment } & L & 0.90 & 0.82 & 1.36 & 0.88 \\
\hline \multicolumn{2}{|c|}{ Unit labour costs } & DLN & 1.09 & 0.94 & 0.87 & 1.20 \\
\hline \multicolumn{2}{|c|}{ Effective exchange rate } & DLN & 1.20 & 1.14 & 1.03 & 1.04 \\
\hline \multicolumn{2}{|l|}{ Oil prices } & DLN & 1.37 & 1.05 & 0.99 & 1.81 \\
\hline
\end{tabular}

Note: Transformations: $\mathrm{D}=$ first difference; $\mathrm{LN}=$ logarithm; $\mathrm{L}=$ level. $\mathrm{BC}$ is the Brand and Cassola (2000) model; $\mathrm{CV}$ is the Coenen and Vega (1999) model.

1 This table reports the ratio of the MSE of the out-of-sample forecasts for the model including the indicator variable to the MSE of the simple univariate time series model of inflation.

Source: Nicoletti-Altimari (2001), Table 1a, p 39.

Other studies (reported briefly in Masuch et al (2001)) also point to money have leading indicator properties for other key macroeconomic variables. In particular, annual growth rates of M1 have been found to help predict future developments in real activity about one year ahead. ${ }^{16}$

15 In particular, since the money-based projections are not derived from a structural model of the economy, they do not offer a basis for calibrating the magnitude of the appropriate interest rate response to counter emerging inflationary or deflationary pressures.

16 In addition to the formal econometric studies discussed above, central banks' staff normally undertake a regular detailed analysis of monetary data. This analysis extracts the information from monetary developments that is relevant for monetary policy decisions, and thus tries to identify special factors or portfolio shifts which distort the relation between money and prices. A detailed discussion of the framework used for this analysis in the case of the ECB - including the judgmental and institutional analysis that complements econometric techniques - is provided in Masuch et al (2001). It is noteworthy that central bank staff who closely monitor developments in financial and banking markets are often in a position to interpret and correct "headline" monetary developments using "off-model" information that is not incorporated into econometric studies. 
This discussion therefore suggests that - at least on the basis of euro area monetary aggregates empirical support exists for the following assertions: first, a stable long-run relationship between money, prices and a small number of other key macroeconomic variables exists; and second, monetary developments are leading indicators of future price developments, especially at longer horizons.

\section{(c) Money as a proxy for unobserved variables: the output gap}

Research on Taylor rules has emphasised the importance of "real-time" data uncertainty for monetary policy decisions. In particular, a number of studies of the United States have found that uncertainty arising from revisions to output gap and inflation estimates may lead to a significant deterioration in the performance of Taylor-like monetary policy rules (Orphanides (2000)). Less energy has been devoted to investigating money's potential role as an information variable in this context. However, if measures of money are subject to fewer revisions - and on average of lesser magnitude than estimates of real output - then monetary aggregates may play a significant role in providing timely and "steady hand" information about the current state of the economy.

In a recent paper, Coenen et al (2001) pursue this avenue of research. In a model with rational expectations, nominal inertia and an apparently totally passive status of money - along the lines of the New Keynesian benchmark model discussed in Section 3 below - monetary developments are shown to be of great help to the policymaker, since money balances react to the "true" level of income, whereas the central bank is assumed to receive only a noisy measure of output. To be sure, the extent to which monetary data enhance the available information set depends crucially on the effort that monetary authorities exert in collecting monetary statistics and undertaking monetary analysis.

\section{(d) Money as a proxy for unobserved variables: monetary and financial conditions}

The money stock can serve as a proxying index also along a different dimension. In a recent paper, Nelson (2002) emphasises the effects of monetary policy upon a whole "spectrum of rates" - over and above that manoeuvred by the central bank - as the driving force within the transmission mechanism. However, a large part of the complete set of yields that matter for aggregate demand is unobservable to monetary authorities. Hence, if the demand for money can be thought of as a function of a broad set of yields besides those observed in securities markets, then movements in money aggregates would convey information that the central bank would not otherwise be able to extract from alternative indicators.

In fact, the historical association between protracted episodes of money growth in excess of some sustainable reference rate and the build-up of financial imbalances and asset price bubbles can probably be interpreted in this light. In periods of financial turbulence the implicit rate at which market participants discount future expected earnings from asset portfolios may vary in ways that are both unpredictable and unobservable to monetary authorities. In these circumstances, a simple comparison between the short-term rate manoeuvred by the central bank and some interest rate benchmark, based say on a Taylor rule, may not be an accurate measure of the prevailing monetary conditions as perceived by market participants. By contrast, monetary quantities - primarily due to their link to credit - have a powerful (incremental) role to play as indicators of the actual stance.

Issing (2002) brings some suggestive evidence to this effect. He analyses three past episodes which, in hindsight, are regarded as having involved large, if unintentional, monetary policy mistakes. In all three cases he investigates whether a policy taking the quantity theoretic equation seriously, and using a money stock indicator as a gauge for the prevailing conditions, could have been instrumental in yielding a better macroeconomic outcome.

Graph 2, which we borrow from that contribution, depicts the evolution of some key indicators in the 1920 s and early 1930s in the United States in the face of a major build-up and subsequent collapse of equity prices. The excess money measure used in the graph is defined as the difference between the

Such analysis therefore often adds to the policy-relevant information in monetary developments, extending their relevance beyond what would be suggested by the econometric studies reported above alone. 
actual growth rate of nominal broad money and the rate that would be implicit in the quantity relation with real income growing at its potential rate, inflation at the central bank's implicit objective, and velocity at its long-term trend. ${ }^{17}$

\section{Graph 2}

The United States in the 1920s: excess money growth, real asset price growth and monetary policy

Annual percentage changes

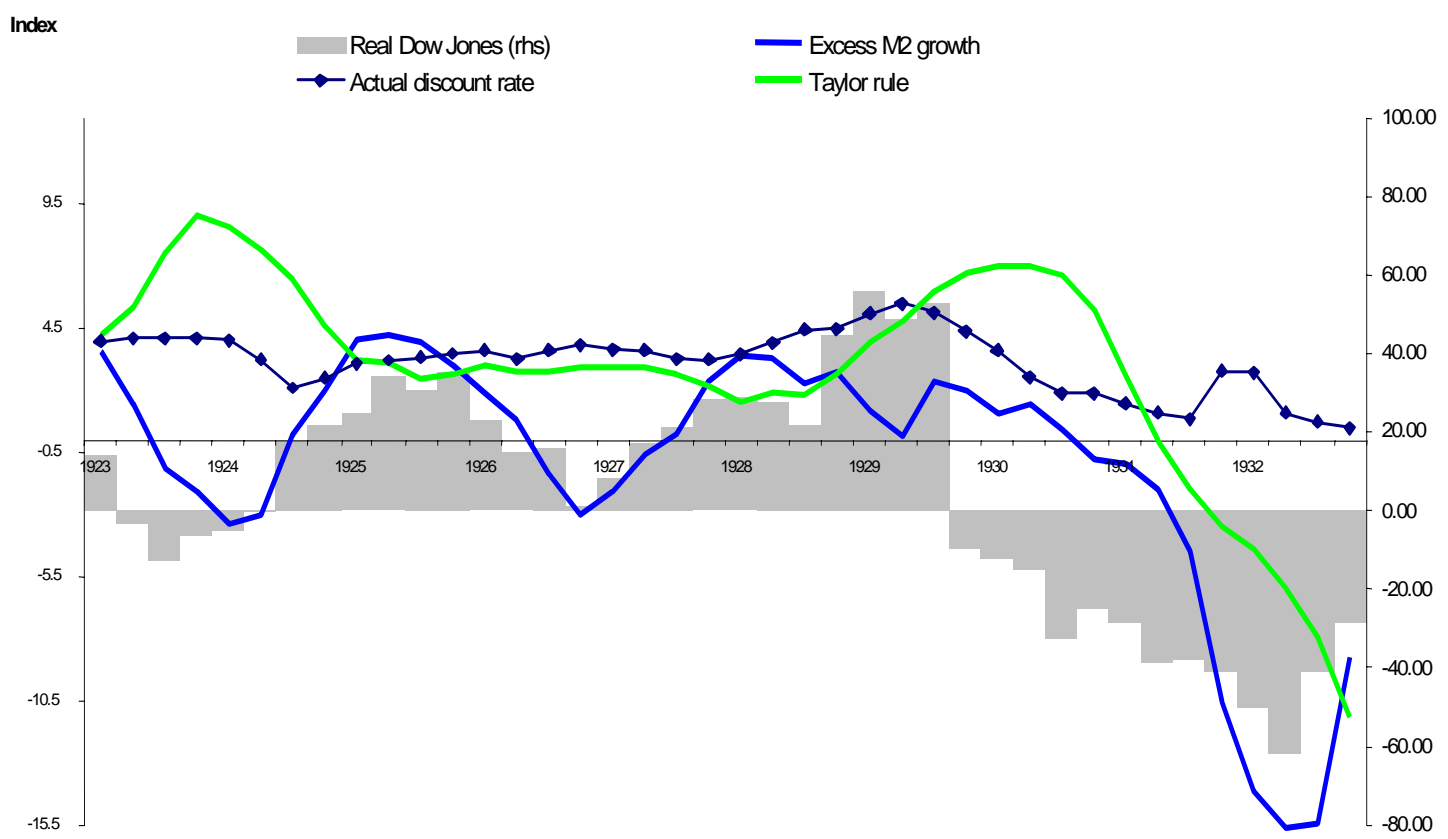

Note: Excess money growth is defined as $\Delta_{4} e=\Delta_{4} m-\left[\Delta_{4} p^{*}+\Delta_{4} y^{*}\right]+\Delta_{4} v^{*}$, where $\Delta_{4}$ denotes the four-quarter difference operator and $m, p^{*}, y^{*}$ and $v^{*}$ stand for (logs of) the actual stock of M2, the price objective, real potential GDP, and the long-term velocity of circulation, respectively. The price objective is normalised to 1 , potential output is obtained applying an HP-filter to actual real GDP, trend velocity for 1923-30 is constructed by interpolating a linear trend to realised velocity over 1921-29, and by imposing a structural break afterwards to reflect the sharp contraction in nominal GDP, primarily led by a fall in producer prices. The Taylor rule has been calibrated to an equilibrium real interest rate equal to the average real discount rate observed in the first two quarters of 1923, and imposing an inflation coefficient of 1.5 and an output gap coefficient of 0.5 .

Source: Issing (2002).

Notwithstanding its purely descriptive nature, this exercise is instructive. It suggests that a quantity measure would have conveyed information which was not forthcoming from a pure analysis of the interest rate used by the Fed in its operations. It shows that, had the Fed looked at a measure of excess money growth, had it not rejected the then novel normative framework offered by the quantity theory of the business cycle, it would have probably realised that monetary policy was too lax, not too tight, for much of the 1920s. ${ }^{18}$ Intriguingly, the measure of excess money growth appears to move in sympathy with the profile of the histograms which represent the growth rates of real stock prices in New York. It becomes positive - and significantly so - in those years in which the market is most buoyant. And it turns negative when the market pauses or falls. Perhaps, one can conclude, money was growing too fast in the years immediately preceding the crash, compared to the long-term necessities of an inflation-free economy operating at potential. Perhaps, that excess of monetary injection was spilling over into the purchase of financial assets. However, looking at the discount rate

17 See the note to Graph 2.

18 That the stance of policy may have been too lax in the later phase of the asset price build-up of the 1920s, besides being a long-standing contention of some prominent representatives of the Austrian School at the time, has been recently remarked by Bordo and Jeanne (2002). 
only, to the exclusion of the monetary indicator, and measuring the historical path of the discount rate against the benchmark provided by the Taylor rule, one would draw the opposite indication. The extent of the abrupt policy reversal in the first half of 1929, which many contemporary observers quote as a primary cause of the disorderly fall in the market, is also more apparent from the quantitative than the interest rate indicator.

\section{Graph 3}

\section{Japan in the 1980s: \\ excess money growth, real asset price growth and monetary policy}

Annual percentage changes

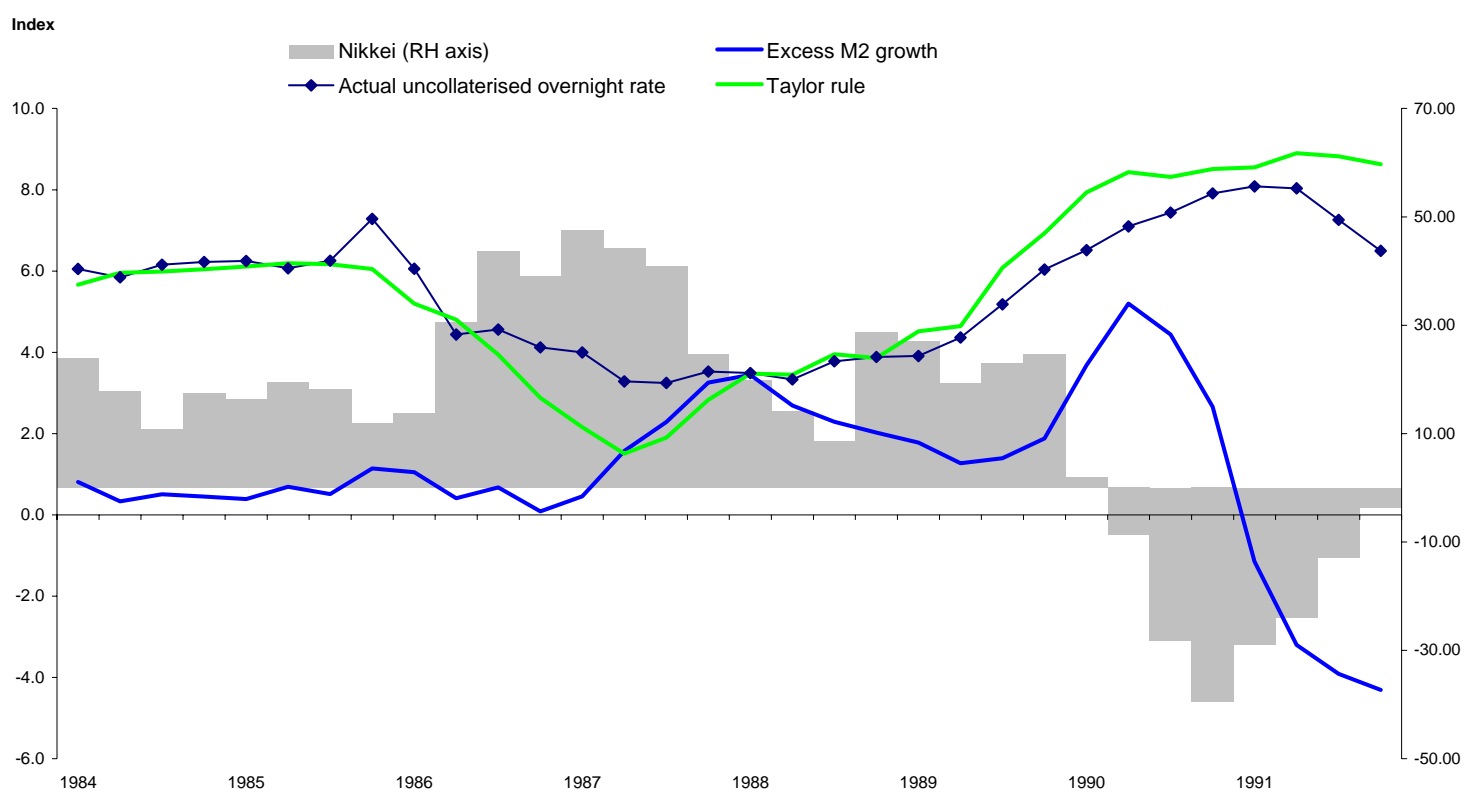

Note: Excess money growth is defined as $\Delta_{4} e=\Delta_{4} m-\left[\Delta_{4} p^{*}+\Delta_{4} y^{*}\right]+\Delta_{4} V^{*}$, where $\Delta_{4}$ denotes the four-quarter difference operator and $m, p^{*}, y^{*}$ and $v^{*}$ stand for (logs of) the actual stock of M2+CDs, the price objective, real potential GDP, and the long-term velocity of circulation, respectively. The Bank of Japan's implicit inflation objective has been set equal to a yearly rate of $1.7 \%$ (the average of the Japanese CPI inflation between 1984 and 1991), potential output is obtained applying an HP-filter to actual real GDP, and trend velocity is constructed by interpolating a linear trend to realised velocity over a 20-year period starting in 1980. The Taylor rule has been calibrated to an equilibrium real interest rate equal to the average real uncollateralised overnight rate observed in the first two quarters of 1984, and imposing an inflation coefficient of 1.5 and an output gap coefficient of 0.5 .

Sources: Bank of Japan; ECB staff calculations.

A similar picture emerges from the Japanese data (Graph 3). While a Taylor rule would have signalled an appropriate-to-tight stance of policy until well into 1989, excess money was building up in the second half of the 1980s, finally at an accelerating pace. ${ }^{19}$ Apparently, the Bank of Japan had expressed early concerns that rapid money growth might predispose the "dry wood" needed to set the asset market on fire. But probably no tightening - in excess of that already apparent in the data - could have been justified to the public on the back of persistently subdued inflation and growing measures of productivity. Again, it seems that a monetary policy gauge focused on inflation and a measure of slack only - to the neglect of money - would have failed to sound the alarm. Furthermore, alternative

19 McCallum (2000) confirms the good fit of a Taylor rule to the actual policy orientation of the Bank of Japan in the 1980s. He also finds that a rule involving a target for base money growth would have provided important insights to the policymakers in those difficult circumstances. 
indicators, such as private credit, may at times outperform broad money in signalling that observed swings in asset prices are abnormal and may prelude financial distress. ${ }^{20}$

Of course, at times shocks to money demand may obscure the message that money indicators convey. Therefore, it is crucial that central banks are able to filter crude monetary data in order to extract the underlying signal of future risks to prices.

\section{Conceptual considerations}

The basic theoretical justification for assigning a prominent role to money in a monetary policy strategy lies in the following fact: it is simply impossible to observe high and sustained inflation without systematic monetary accommodation. Similarly, a prolonged and substantial deflation requires monetary contraction.

What is meant by "monetary accommodation"? In the past, this concept has often been identified with a central bank's adoption of an interest rate rule. In other words, rather than pursuing a quantitative target for money, the central bank sets an operational target for a nominal short-term interest rate. In a famous article, Sargent and Wallace (1975) challenged this practice on the basis that such a regime leaves the price level indeterminate and would thus tolerate (or even trigger) prolonged periods of high inflation.

However, following McCallum (1981), it was recognised that "monetary accommodation" was not synonymous with an interest rate rule as such. In particular, McCallum showed that an interest rate feedback rule would not lead to nominal indeterminacy if the rule was defined so as to have an impact on, say, the price level in the upcoming period. McCallum showed that monetary authorities could set monetary policy in terms of an interest rate, provided that the way in which the policy interest rate was manoeuvred reflected a concern about the future evolution of some nominal magnitude. ${ }^{21}$

However, this line of analysis suggested that the "nominal magnitude" did not necessarily need to be money. It led to the conclusion that central banks could adopt a policy rule whereby the policy interest rate fed back from a set of endogenous variable indicators, but not including money. Such a moneyless framework still provided the economy with the anchor that it needed for nominal values to be pinned down. ${ }^{22}$

Formulated in this manner, McCallum's result had far-reaching consequences for the theory and practice of monetary policy. It gave rise to the flourishing literature on interest rate rules for monetary policy, which constitute one building block of what Goodfriend and King (1997) have named "the new neoclassical synthesis" in macroeconomics. This framework maintains that it is, in general, possible to develop guidelines for monetary policy aimed at price stability without having to specify policy in terms of a monetary aggregate.

To be sure, the guiding principles stemming from this framework exhibit recognisable "monetarist" features: they are wedded to neoclassical reasoning; they are built on the presumption that inflation is ultimately a monetary phenomenon, which can ultimately be governed by the central bank given that the latter has the power to supply base money and thus to set the overnight interest rate; and they recommend making low and stable inflation the primary objective of monetary policy. Nevertheless, this approach departs decisively from the heart of monetarism by rejecting the monetarists' practice of organising monetary analysis largely in terms of the interplay between the supply of money and the demand for real balances.

20 Alternative indicators, such as private credit, may at times outperform broad money in signalling that observed swings in asset prices are abnormal and may prelude financial distress. The close correlation between domestic credit growth and the change in (a composite indicator of various) real asset prices is stressed in a recent contribution by Borio and Lowe (2002).

21 This insight was subsequently refined by Woodford (2002, Chapter 2), who argued that, in order to pin down prices, the central bank need not adjust its interest rate instrument in response to nominal quantities. All that is needed is a reaction function linking the policy interest rate to endogenous variables. More on this below.

22 Woodford (2002, Chapter 2), in particular, raises this point with force. 
Therefore, while recognising the validity and robustness of the long-run link between monetary growth and inflation, prominent contributors to this branch of literature argue that money should not be assigned a special status in the monetary policymaking process. Monetary policy should not pay special attention to developments in monetary aggregates because the observed long-run relationship between money and prices says nothing about the direction of causality running between them (Galí (2001)). In this context they argue that paying excessive attention to monetary developments simply exposes monetary policy decisions unnecessarily to the vagaries of money demand.

Against this background, the scope of the remainder of Section 3 is rather limited. Working within the new neoclassical synthesis framework briefly outlined above, the section evaluates whether the strong policy conclusions drawn above are justified. This discussion is organised in two parts. First, we outline the basic new neoclassical synthesis model. Second, we show that within this environment a class of popular rules that do not include money can give rise to self-fulfilling fluctuations.

(a)

\section{A non-monetarist model}

An extremely simplified version of the new neoclassical synthesis model can be reduced to these three summary conditions: ${ }^{23}$

$$
\begin{aligned}
& y_{t}=\gamma_{0}-\gamma_{1}\left(i_{t}-E_{t} \pi_{t+1}\right)+E_{t} y_{t+1}+e_{t} \\
& \pi_{t}=\delta_{0} E_{t} \pi_{t+1}+\delta_{1}\left(y_{t}-y^{*}\right)+u_{t} \\
& \left(m_{t}-p_{t}\right)=\eta_{0}+\eta_{1} y_{t}-\eta_{2} i_{t}+z_{t}
\end{aligned}
$$

where, other than the short-term nominal interest rate under the control of the central bank, $i_{t}$, and the inflation rate, $\pi_{t}$, all variables are expressed in logarithms: $y_{t}$ is output, $p_{t}$ is the price level, $m_{t}$ is (base) money, and $e_{t}, u_{t}$ and $z_{t}$ are stochastic error terms. $E_{t-1} x_{t}$ represents the expectation of $x_{t}$ at time $t-1$, where $t$ is (discrete) time. ${ }^{24}$

Equation (1) (with $\gamma_{0}$ and $\gamma_{1}$ both positive) is a dynamic stochastic IS curve which can be derived from the Euler condition associated with the representative household's savings decision by imposing standard market clearing conditions. It states that output $y_{t}$ is related (negatively) to the contemporaneous real interest rate and (positively) to expectations of future output conditions.

Equation (2) (with $\delta_{1}>0$ and $0<\delta_{0}<1$ ) is a forward-looking Phillips curve, which can be derived from optimal pricing decisions of monopolistically competitive firms facing constraints on the frequency of future price changes. The current rate of inflation responds to expectations of future inflation and the current level of resource utilisation, as proxied by the output gap. Equation (3) is a money demand relation, which is obtained from the optimal marginal conditions on consumption and money holdings, assuming money provides liquidity services that are valued by the agent along with consumption goods. It states that real money balances vary positively with income and negatively with the nominal interest rate.

Equations (1) and (2) are central to the new neoclassical synthesis view of macroeconomics. Assuming a household utility function that is additively separable between consumption and real money balances, these two equations describe the dynamics of inflation and output as a function of the short-term nominal interest rate only. Except for the nominal interest rate term appearing in equation (1), the system is block-recursive: the transmission mechanism of monetary policy operates solely via prices (the cost of borrowing), and not via quantities (eg the availability of credit or money holdings).

\footnotetext{
23 Seminal examples of this line of thought can be found in Woodford (1997, 2002, Chapter 4), Goodfriend and King (1997), Clarida et al (1999, 2000), McCallum (2001) and the rightly celebrated book by Taylor (1999).

24 The contemporaneous inflation rate is defined as $\pi_{t}=p_{t}-p_{t-1}$.
} 
In principle, the first two equations could be made entirely autonomous, provided the interest rate manoeuvred by the central bank is itself made insensitive to any magnitude which does not appear in either equation (1) or equation (2). A very general formulation of such a rule is provided below:

$$
i_{t}=\Phi\left(y_{t}, E_{t} y_{t+1}, \pi_{t}, E_{t} \pi_{t+1}, e_{t}, u_{t}\right)
$$

where, notably, the set of indicators deemed relevant for policy does not include $(m-p)_{t}$.

Assuming this policy rule performs well - in a sense to be made explicit shortly - "the monetary sector [becomes] basically an afterthought to monetary policy analysis. The familiar LM curve only serves the purpose of determining the quantity of money given the price level, real income, and the nominal interest rate" (Kerr and King (1996)). In this context, equation (3) would appear superfluous. It only serves to specify the quantity of money needed to clear the money market at the interest rate dictated by the policy rule. Monetary dynamics are thus irrelevant to the determination of price developments and should not concern a central bank aiming at price stability.

Taking these results at face value, the autonomous (or moneyless) policy rule (equation (4)) is both analytically convenient and capable of simplifying the task confronted by a central bank. However, this prima facie view is insufficient.

\section{(b) Is money useful as nominal anchor?}

Technically, it is not sufficient to demonstrate that a moneyless rule exists which is consistent with a particular desired equilibrium. One has also to demonstrate that the desired outcome is the unique equilibrium associated with that rule. In other words, one has to demonstrate that the posited policy rule avoids situations in which the central bank, quite unintentionally, permits economic fluctuations (and, in particular, deviations from price stability) which arise solely from self-fulfilling expectations. If a policy rule were to tolerate these situations, not only would the response of the economy to exogenous (fundamental) shocks be indeterminate, but endogenous variables might also start reacting to random variables unrelated to the structure of the model (leading to "sunspot equilibria" where outcomes are determined solely by self-fulfilling private expectations).

Such a situation would clearly pose a severe problem for central banks: apparently well designed rules would not ensure price stability, at least under a sufficiently wide range of conceivable circumstances. This observation is what motivates the quest for uniqueness of equilibria in monetary models and gives justification to the role money can play as a nominal anchor in monetary economies.

\section{(c) Two moneyless rules}

The literature has pursued two different specifications of the autonomous or moneyless policy rules discussed above.

\section{(c.i) Target rules in a linear-quadratic policy problem}

According to the target rule approach, the interest rate rule for monetary policy is defined implicitly as the solution to an optimisation problem facing the central bank. In the literature it is often assumed that the central bank selects its interest rate policy by minimising a loss function expressed in terms of the deviations of inflation and output from mandated objectives $\left(\pi^{*}\right.$ and $\left.y^{*}\right)$, taking the structure of the economy as given:

$$
L=\frac{1}{2} E_{t}\left\{\sum_{j=0, \infty} \beta^{j}\left[\left(\pi_{t+j}-\pi^{\star}\right)^{2}+\lambda\left(y_{t+j}-y^{\star}\right)^{2}\right]\right\}
$$

In most applications, the central bank finds the interest rate path which minimises a quadratic loss function expressed in terms of deviations of objective variables from target (equation (5)), subject to 
the linear constraints (equations (1) and (2)) of the new neoclassical synthesis model (hence "linearquadratic"). ${ }^{25}$

$\lambda$ is the relative weight attached to output stabilisation in the central bank's policy preferences. ${ }^{26}$ Can this linear-quadratic policy regime inoculate the economy against the risks of chronic instability which have been briefly described at the beginning of Section 3(b)?

The answer is: not always, at least under rational expectations. Under this regime, equation (4) takes the following form:

$i_{t}=\chi_{0}+\chi_{1} e_{t}+\chi_{2} u_{t}$

for an appropriate specification of the constant term $\chi_{0}$ and the reaction coefficients $\chi_{1}$ and $\chi_{2}$. However, as proved by Woodford (1999) and Svensson and Woodford (2003), the model defined by equations (1), (2) and (4a) admits a large multiplicity of bounded solutions, in the hypothesis that private expectations fully internalise the authorities' reaction function (4a) as part of the policy regime which they face. These include both solutions implying different equilibrium responses to fundamental shocks $\left(e_{t}\right.$ and $\left.u_{t}\right)$, and solutions involving responses by the central bank to non-fundamental states of the economy, such as sunspots in private expectations.

At root, this multiplicity result stems from: first, the rational expectations definition of an equilibrium, which, by itself, makes the economy particularly sensitive to revisions in expectations; and second, the possibility that a policy of elastic currency leads the private sector to actually act on those expectations by drawing more or less money from the central bank at the fixed policy rate. In such an environment, a policy rule like equation (4a) - which specifies each period's nominal interest rate as a function solely of exogenous states or shocks - does not provide the economy with a defence against off-equilibrium revisions in expectations. ${ }^{27,28}$

25 Formulating the problem using this linear-quadratic specification has presentational and computational advantages. In particular, it yields linear policy rules which are invariant to (additive) uncertainty, ie they exhibit so-called certainty equivalence. However, it is not certain whether such a loss function is a good approximation for central banks in practice. This is particularly relevant for central banks which have a price stability objective or a clear inflation target and no or only a subordinated mandate to simultaneously contribute to output smoothing.

26 The linear-quadratic (or "target rule") approach to monetary policy has been strongly advocated by Svensson (1999a, 1999b).

27 Two issues related to the characterisation of target rules given above need to be kept distinct. One issue is whether a reaction formula such as (4a), which results from the solution to the linear-quadratic dynamic programming problem represented by (1), (2) and (5), can be consistent with an optimal equilibrium in which inflation remains solidly anchored around the target value $\pi^{*}$ and inflation and output evolve solely as a function of the fundamental shocks identified in the structural representation of the model. A distinct issue is whether such situation is the unique possible non-explosive solution to the equilibrium conditions which can be supported by a reaction rule such as (4a). Or there may exist other possible equilibria which are equally consistent with (4a) but imply (undesirable) dynamics of the model state variables, whereby these variables fluctuate in unpredictable ways in response to the fundamental shocks (and, in addition, may also respond to non-fundamental shocks which have no analytical representation in the equations describing the structural dynamics of the model). In this respect, one should bear in mind that many numerical experiments available in the literature on the performance of target rules of the sort described in Section c.i. are either conducted on the basis of backward-looking models, or - in case they use a purely forward-looking structure as in the text above - do not explicitly tackle the issue of uniqueness or, similarly, assume that private expectations do not internalise (4a) when forming expectations of policy action. An example of the first approach is Rudebusch and Svensson (1999), which will be further discussed in Section 4 below. An example of the second approach is Clarida et al (1999) and Jensen (2002a). These two papers are briefly discussed in footnote 31. It should also be borne in mind that the failure of a rule like equation (4a) to induce determinacy is not confined to the case of rational expectations. Evans and Honkapohja (2001) discuss the case in which private agents revise expectations according to an adaptive learning mechanism while the central bank solves its model under a rational expectations assumption. They show that in this case private expectational errors - due to learning - do not receive an adequate response by the central bank, which only reacts to the fundamental shocks, ut, and et. Hence, expectational errors of the past tend to become ingrained and lead to a process of cumulative divergence of the economy from the rational expectations equilibrium.

28 Woodford (2000b) discusses analytical ways to circumvent indeterminacy problems in purely forward-looking inflation targeting environments of the type expounded in this Section. These solutions generally involve recourse to optimal delegation schemes whereby the loss function assigned to the central bank is modified relative to the one which reflects the 'true' preferences of society - a function of quadratic deviations of output from potential and inflation from target, such as in (5) - by inclusion of additional lagged values of target variables. The purpose of these additions is to induce an implied reaction rule which makes the nominal interest rate a function of lagged endogenous variables in addition to the terms figuring in (4a). Dependence of the reaction function on such variables is a necessary - though not sufficient - condition for determinacy. Examples of such delegation schemes include the options of charging the central bank with stabilisation of the 
To conclude this subsection, rules derived within the target rule framework (whereby the monetary authority reacts to the fundamental shocks hitting the economy) do not appear to pass the test of uniqueness. Rather, in extreme circumstances, they could lead to bursts of inflation deriving from self-fulfilling changes in expectations. ${ }^{29}$

\section{(c.ii) Moneyless instrument rules: the Taylor principle}

A second family of policy rules which can "close" the model without reference to equation (3) are those in which the policy interest rate is made a direct function of endogenous variables, such as inflation and output (eg Taylor (1993)).

Recent variants of this approach typically use expected (instead of realised) inflation, as in the following specification:

$i_{t}=r^{*}+\pi^{*}+\alpha\left(E_{t} \pi_{t+k}-\pi^{*}\right)+\beta\left(y_{t}-y^{*}\right)$

where $r^{*}$ is a parameter of the system (the equilibrium real interest rate) and $k$ is some forecasting horizon deemed relevant for monetary policy.

Clarida et al $(1999,2000)$ provide a thorough investigation of the properties of a system in which the central bank behaves according to equation (6). They conclude that a sufficient condition for the rational expectations equilibrium to be unique in a macroeconomic model similar to equations (1) to (3) is that the interest rate instrument be made to increase more than one for one in response to increases in forecast inflation, ie $\alpha>1^{30,31}$ The numerical constraint that $\alpha>1$ has come to be known

price level - rather than inflation rate - as in Vestin (1999), and the proposals to include a nominal output growth term (Jensen, 2002b) or an interest rate smoothing term (Woodford, 1999) in the central bank's assigned loss function. Svensson and Woodford (2003) take a step further by exploring history-dependent variants of inflation targeting which are inherently robust to multiplicity problems. They conclude that robustness of this kind can be achieved within an inflation forecast targeting universe only at the cost of contaminating the dynamic optimisation analytics of a pure targeting procedure with elements of commitment to an instrument rule of the type that is discussed in the text under Section c.ii. In particular, they show that a way to achieve determinacy is to amend the general targeting procedure described in the text with a commitment to a particular direct interest rate response, whereby the central bank reacts to deviations of private expectations of inflation and output gap from the central bank's forecasts. The relative intricacy of this solution, however, seems at odds with the simplicity and transparency of inflation targeting in its pure original incarnation described, say, in Svensson (1997, 1999a).

29 A distinct issue is whether a target rule such as the one described in this section - and involving a monetary policy reaction function of the type represented in equation (4a) - is welfare-optimising or can be found to be dominated by an alternative rule obtained under precommitment. As shown in Woodford (1999), discretionary policymaking in a model incorporating forward-looking behaviour is indeed typically characterised by a stabilisation bias, ie it may lead to a suboptimal degree of proactivism in the central bank response to shocks (via equation (4a)). Therefore, when agents' decisions depend on their expectations of the future state of the economy - as in the model sketched in equations (1) to (3) - there are gains to be had from a more inertial pattern of response. Woodford (1999) and Svensson and Woodford (2003) investigate various mechanisms which can induce inertia in discretionary monetary policymaking, among which they propose a number of optimal delegation schemes whereby the central bank is assigned an appropriately modified loss function. More recently, Söderström (2001) has investigated whether assigning the central bank a loss function which includes a term in money growth can indeed induce the type of inertial behaviour which can be expected to enhance welfare. Since money is demand-determined in his model, its rate of growth is related to the change in the nominal interest rate and the growth rate of output. Therefore, he concludes: "a suitably designed target for money growth may introduce inertia in to the discretionary policy rule, leading to improved outcomes". He also notes that "this mechanism is entirely due to money being related to other variables in the economy, and not due to any indicator role for money".

30 Bernanke and Woodford (1997) come to broadly the same conclusions using a model similar to equations (1) and (2) but with a slightly modified timing of price revision by firms.

31 Strictly speaking, Clarida et al $(1999,2000)$ find that $\quad>1$ is a sufficient condition for determinacy only when $=0$ and the stabilising threshold of dips below unity as increases. They also establish an upper bound for beyond which determinacy conditions are violated. This upper bound is well above the numerical value for which was conjectured by Taylor (1993) to be stabilising. However, the result of Clarida et al and the similar result of Jensen (2002a) - within an inflation forecast targeting environment similar to the one expounded in Section c.i. - that determinacy can be achieved in a forward-looking model by postulating that the central bank is committed to a rule that makes the policy interest rate a sharply increasing function of expected future inflation has been questioned by Svensson and Woodford (2003). They contend that such a monetary policy reaction function may not be "a fully operational specification of the monetary policy rule [...] as the central bank's instrument is expressed as a function of endogenous variables (conditional expectations of future inflation and output) that themselves depend upon current monetary policy. In practice, the bank would have to forecast the paths of the endogenous variables, given its contemplated action. This forecast should depend only upon information about the exogenous disturbances, and the bank's contemplated policy; thus, an operational version of the 
in the most recent debate as the Taylor principle, as it was first conjectured in the seminal Taylor (1993) article.

The issue in this subsection is thus whether this policy prescription - which suggests that it is sufficient for central banks to ignore money and set interest rates solely on the basis of non-monetary indicators - is robust across a sufficiently broad array of variations to the basic model sketched above. The answer developed here is once more: no, at least under rational expectations. In what remains of this subsection we shall therefore review the cases in which the Taylor principle - by itself - fails to deliver a unique and determinate solution to the policy problem of keeping macroeconomic magnitudes safely anchored to the stated objectives of policy.

\section{(ii.1) The Taylor principle with a non-Ricardian government}

The macroeconomic model described by equations (1) and (2) and the policy rule (equation (6)) is not only moneyless; it also lacks any form of interest-yielding public liability. This is difficult to justify since, in general, the nominal interest rate set by the central bank will affect the terms at which the public debt is rolled over.

Only if the fiscal authority always stands ready to adjust its primary surplus in response to any past development which caused a deviation between the actual stock of public debt and some specified long-term target can the relationship between interest rate and public finances be ignored. For this to be the case, any interest rate increases implemented by the central bank in pursuit of price stability would have to be accompanied by an appropriate fiscal response to offset the consequences of higher real borrowing costs for the rate at which public debt is accumulated (eg in the case of higher real interest rates, the primary surplus would have to increase). Leeper (1991), in a seminal contribution, defined such fiscal arrangements as "passive". More recently, Woodford (2000a) refers to such accommodating fiscal regimes as of a "Ricardian" type.

In a less than Ricardian fiscal regime, the macroeconomic system (equations (1) to (3)) is incomplete. One needs to augment it with the government flow budget constraint to check the determinacy conditions. However, the conditions turn out not to be satisfied if the inflation coefficient in equation (6) is above unity. ${ }^{32}$

Moreover, Woodford (2000a) has shown that even the existence of a debt limit that eventually constrains the growth of public debt is not sufficient for the fiscal regime to qualify as "Ricardian" in Woodford's sense. If the fiscal authority is ultimately committed to modify its course once some extreme debt limit is breached, but is nonetheless less than forthcoming in reacting to changes in monetary policy before that limit is approached, then a monetary policy rule embodying the Taylor principle (like equation (6)) would not - by itself - guarantee price stability. As shown by Woodford, in these circumstances, the equilibrium would be characterised by an inflationary spiral, in which progressively higher rates of inflation lead to higher real interest rates, hence higher rates of growth of nominal government liabilities, which in turn lead to higher rates of inflation. ${ }^{33}$

These findings suggest that a monetary policy regime which blindly responded to inflation forecasts and the output gap while respecting the Taylor principle would wind up accommodating inflationary developments. Asset stocks, eg money, by contrast, may be a useful source of information for monetary policymakers which helps to stabilise the economy.

policy rule, in which the central bank's procedure is completely specified as an algorithm, is equivalent to a rule that sets the nominal interest rate as a function of the exogenous disturbances, and leads to indeterminacy".

32 Technically, the system would then have four equations: (1) to (3) and the flow budget constraint of the government. It can then be shown that, with a less than Ricardian fiscal authority, one needs $<1$ in order to obtain two stable and two unstable eigenvalues. The latter are needed because the set of endogenous variables include two predetermined and two "jump" variables.

33 The irony in this is that a monetary policy rule that would conventionally be thought to be anti-inflationary may instead lead to an inflationary spiral when combined with an unsuitable fiscal policy. A monetary policy episode which could confirm these perverse dynamics was studied by Loyo (1999). 
As we argued above, equations (1) to (3) constitute a reduced-form representation of an underlying money-in-the-utility structural model with a zero cross partial derivative between consumption and real balances. A key issue, which we have left in the background so far, is what measure of money appears in the utility function.

In the conventional specification discussed above, the implicit assumption is that the liquidity services which are valued by the representative agent are associated with the real money balances the agent holds at the end of the period after all market transactions have been concluded. This seemingly innocuous timing assumption has a very important implication: goods can be exchanged for other goods and for bonds without the intermediation of money.

However, money is typically seen as distinct precisely because it acts as a medium of exchange. In other words, the conventional new neoclassical synthesis model - in the version above - does not seem adequately to capture the fundamental rationale which underlies the demand for a nonremunerated asset like money, ie while inflicting a cost in terms of forsaken interest, money helps to facilitate a number of transactions which would not otherwise be possible. Holding currency before commencing trading may be what provides agents with the utility services which motivate a monetary economy in the first place.

Carlstrom and Fuerst (2001a) amend the model to allow for a genuine transactions role of money. They assume real money balances enter the utility function at the beginning of the period, before trade in goods takes place. The Taylor principle does not survive this amendment for a model calibration similar to that used by Clarida et al (2000). The same result - that real determinacy requires an inflation coefficient in equation (6) below unity - is derived by Christiano and Rostagno (2001a,b) and Benhabib et al (2001c). The first two papers use a suite of cash-in-advance and limited participation models with flexible prices and an elastic labour supply. The third paper uses a money-in-theproduction-function framework. All papers uncover indeterminacy and/or equilibrium cycles under a rule embodying the Taylor principle.

Here, again, a minor (timing) modification to the underlying framework suffices to overturn the basic policy message. A monetary policy blindly following the Taylor principle and ignoring monetary developments is associated with an indeterminate equilibrium, where the economy is left without an anchor and fluctuates unpredictably around the "virtuous" equilibrium.

\section{(ii.3) The Taylor principle from a global perspective}

It should be emphasised that equations (1) to (3) are derived by linearising a set of non-linear optimal conditions around a non-stochastic steady state. However, any analysis based on linearisation must be interpreted as being local in a neighbourhood of the steady state and only valid under sufficiently small perturbations of the system. How small must the perturbations be to justify such a local analysis?

An emerging strand of literature has started to investigate the properties of Taylor rules such as equation (6) from a global perspective, ie removing the assumption that perturbations are necessarily small. Benhabib et al (2001a), for example, convincingly argue that the standard practice of studying monetary models in a small neighbourhood of the steady state can generate a misleading impression about the set of possible equilibrium outcomes. In particular, even in cases in which rules embodying the Taylor principle guarantee uniqueness of the rational expectations equilibrium locally, they may fail to do so globally. They construct a money-in-the-utility model which closely resembles the one underlying equations (1) to (3) and impose a monetary policy reaction function which explicitly acknowledges the zero lower bound on nominal interest rates. ${ }^{34}$ They find that the mechanical implementation of a Taylor-like monetary policy rule founded on the Taylor principle per se can trap the economy in perverse dynamics. Along these trajectories, explosive inflation expectations - even if divorced from underlying economic fundamentals - end up being systematically validated by the

34 The "lower bound problem" arises from the fact that in a monetary economy the central bank cannot engineer negative nominal interest rates as long as its counterparts retain the option to hold zero interest currency. 
central bank. ${ }^{35}$ In other words, they uncover an uncountable number of equilibrium trajectories invisible from the point of view of the conventional local analysis - which originate in a vicinity of the "virtuous" steady state, and finally converge to a situation in which the nominal interest rate is zero and the monetary policy becomes ineffective.

All that is needed for the economy to start the slide towards the lower bound is that agents - for some reason - come to expect the economy to enter a deflationary phase. In these circumstances, interest rates are constantly being lowered in response to the observed fall in price inflation, and in an attempt to reverse the persistent decline in inflation. However, these efforts are to no avail, because expected future inflation may fall - along a possible equilibrium trajectory - at the same time and ex ante real interest rates are not reduced and continue to be high enough to restrain demand despite falling prices. $^{36}$

\section{(c.iii) Caveats}

Are the sort of multiplicity and stability problems associated with moneyless policy rules something which real world central banks should worry about? Or are they to be confined to the realm of analytical curiosa? In particular, is it likely that some sort of horse race dynamics between an always proactive central bank and constantly overpessimistic private sector expectations may finally ensue which can lead the economy to spiral down to the lower bound? The judgment is still pending and different leading authors hold quite diverging views on this issue of policy relevance. McCallum (2001) maintains that conclusions based on bubbles and indeterminacy arguments are of dubious merit and many of these vanish under a minimum-state-variable criterion for equilibrium selection. Woodford (2002, Chapter 2), on the opposite side, takes these problems seriously. For example, while conceding that "the economy can only move to one of [the downward-spiralling] alternative paths if expectations about the future change significantly, something that one may suppose should not easily occur", he acknowledges that "one must worry that a large shock could nonetheless perturb the economy enough that expectations settle upon another equilibrium". ${ }^{37}$

At the very least, a central bank should note that perverse inflation dynamics have been encountered in simulation exercises of calibrated models used widely in the literature. For example, Rudebusch and Svensson (1999) acknowledge that their experiments with simple versions of Taylor rules such as equation (6) imply that "nominal interest rates would be negative a non-negligible portion of the time". They go on to say that "intuitively, with an estimated equilibrium real funds rate of $2.5 \%$, if inflation ever falls to, say, $-3 \%$, then, with a zero nominal funds rate, the real funds rate is still restrictive, so the output gap decreases and inflation falls even further".

Christiano and Gust (1999) show that the set of policy elasticities to inflation and the output gap under which a Taylor-like rule becomes a source of instability within a limited participation model - with a cash-in-advance timing - is much broader than for conventional specifications of sticky-price and money-in-the-utility models. ${ }^{38}$ Experiments conducted on the basis of an "eclectic" macro-model

35 In other words, an "expectational bubble" can emerge in the price level if the central bank pursues a Taylor-like rule with an inflation coefficient greater than unity.

36 Is this scenario, in which monetary authorities and the private sector in a sense "chase each other" along a sliding path to zero interest and negative inflation rates, a reasonable description of what could happen? Some scholars argue that it is, at least in the case in which the "way to go" between the target stationary equilibrium and the "liquidity trap" stationary equilibrium is sufficiently short and the Taylor coefficient on inflation in the monetary authorities' reaction function is sufficiently large. Benhabib et al (2001a) describe the current situation in Japan as possibly the outcome of such perverse dynamics.

37 The emerging strand of literature on adaptive learning is also split. Bullard and Mitra (2000) find that, under a forwardlooking Taylor rule such as equation (6), the equilibrium with adaptive learning is determinate. By contrast, Carlstrom and Fuerst (2001b) demonstrate the existence of learnable sunspot equilibria in a cash-in-advance model when both the central bank and the private agents learn adaptively. They also prove that, when the central bank is subject to a learning process, while private sector expectations are always rational, sunspot equilibria are always learnable, and thus are indeed a cause for concern.

38 The limited participation model introduces a friction into the workings of the financial markets to the extent that, due to rigidities in portfolio adjustments, a monetary injection at time $t$ is disproportionately absorbed by financial intermediaries and thus channelled to finance investment rather than consumption. This assumption is what allows the model to generate an impulse-response pattern whereby a surprise monetary injection is followed by a fall in the equilibrium nominal rate of interest (liquidity effect) and a rise in output. By contrast, these features are not easily reproduced by competing new 
proposed by Christiano et al (2001) - conflating different sources of nominal frictions, liquidity effects and consumption and investment inertia in a rich stochastic general equilibrium context - confirm that forward-looking proactive Taylor rules produce excess volatility. The same indeterminacy problems are encountered by Levin et al (2001) for forecast-based Taylor rules at horizons exceeding one year ahead across a number of competing models incorporating rational expectations, short-run nominal inertia and long-run monetary neutrality.

This evidence, of course, releases a warning signal in a central bank profoundly concerned about the robustness of its policy course. At the very least, the theoretical and simulation results surveyed in this subsection suggest that decision-makers should broaden - rather than narrow - the set of indicators which they routinely look at to inform decisions. Identifying moneyless policy rules - in the sense defined above - for the sake of parsimony may not be a useful exercise. Moreover, the consequences of adopting a rule narrowly focused on a handful of indicators to the exclusion of others may turn out to be unpleasant. Whether money could help in this quest for a broader perspective, even within seemingly moneyless models, is the subject of the next section.

\section{(c.iv) Addressing the pathologies associated with moneyless rules}

Monitoring monetary developments can protect the economy against some of the pathologies associated with moneyless monetary policy rules described in Section 3(c) above. Although there are parameterisations and timing assumptions in variants of the new neoclassical synthesis model under which conventional Taylor rules lead to good macroeconomic outcomes, other plausible parameterisations and timing hypotheses exist in which these moneyless policy rules may lead to bouts of inflation or deflation. At root, this is because moneyless interest rate policy rules can - under the latter assumptions - be supported by various rates of monetary growth. Each of these money growth rates is associated with a different real outcome for the economy. A central bank concerned with robustness should adopt a monetary policy strategy that would also be effective with regard to its objectives if the economy were better described by the latter set of model assumptions than the former. Such an approach would thus seem to rule out the adoption of moneyless Taylor-like rules.

In circumstances where conventional moneyless rules fail, a policy of money growth monitoring can, in effect, provide the economy with an anchor. Christiano and Rostagno (2001a, 2001b), for example, postulate a policy framework in which a Taylor rule based strategy is followed as long as money growth falls within a specified target range. If that target is ever violated, however, the Taylor rule is abandoned in favour of a Friedman-like constant money growth rule. ${ }^{39}$ They show that the latter escape clause can provide the plain Taylor reaction function with the "servomechanism" needed to remove the undesired trajectories - to which the Taylor rule may lead - from the space of possible events. ${ }^{40}$

neoclassical models, which postulate various sorts of price rigidities. A description of models of this type is provided by Christiano et al (1997).

39 This policy is shown to be benign and non-interfering with the operation of the Taylor rule in the case of a model à la Clarida et al $(1999,2000)$. On the other hand, it would improve economic performance substantially, by eliminating undesired equilibria, if the economy were to be better represented by a cash-in-advance model.

40 It is open to debate whether the switch from a Taylor rule to a Friedman rule would involve a change in the operating procedures used by the central bank, ie whether the central bank would have to renounce its practice of setting a target for a short term interest rate (in a way consistent with the Taylor-rule prescriptions) and begin announcing short-run targets for money growth. In the latter case, it would appear to be of relevance to ensure that the aggregate for which a target is announced is controllable by the monetary authorities with a sufficient degree of precision. Historical experience is indeed consistent with the notion that a switching rule of the type discussed in Christiano and Rostagno (2001) may be implemented both by a continuation of the interest-rate-centred operating procedure and by a change in the operating procedures in favour of one centred on money quantities. Mayer (2001), for example, explains that when the Federal Reserve started setting short-term targets for M1 in January 1970 - reflecting disappointment with recent macroeconomic performance - it established them in the form of the two-month (in 1975 extended to annual) target growth rates. The federal funds rate was then calibrated to a level estimated to be consistent with hitting the broad money growth target. Conversely, when in October 1979 - out of fears that inflation may have gotten out of control - the Fed embarked on a decisive policy of monetary contraction, it seemed natural to mark the policy change with a discontinuation of the practice to set a target for the funds rate. However, the need to express the money target in terms of a broad aggregate did not seem to pose a problem of controllability of the new target. Mayer states that: "Policy was implemented during this period by estimating the total reserve growth [ie the intermediate target for the narrow monetary aggregate under authorities' control] necessary to meet the money growth target [for the broader official target aggregate] and by holding to the associated path for non- 
The more extreme pathologies associated with non-linearities can also be cured by a suitable transition to a different operating scheme centred upon the targeting/control of monetary aggregates. Benhabib et al (2001b) study the virtues of such a switching regime in the context of providing insurance against the liquidity trap. Svensson (2001) also appeals to the standing possibility for a central bank, at any time, to abandon a Taylor rule and start expanding the money stock by means of purchases of foreign exchange. ${ }^{41}$ Interestingly, apart from the general doubts on the usefulness of Taylor rules for actual policymaking, even among proponents a consensus is emerging on the need to scrap any Taylor-like strategy, should the threat of a deflationary trap materialise. However, this implies that a fully credible commitment to the Taylor rule alone would not be possible in the first place.

The key message contained in these contributions is that the announcement of a definition of price stability - or, alternatively, an inflation or price level target - while a major constituent element of a monetary framework founded on price stability, does not in itself constitute a sufficient guarantee that such an objective will be attained, unless the announcement is supported by a stabilising "rule" which specifies the central bank moves conditional on protracted deviations from equilibrium. This rule is the second major element needed to anchor expectations. Underlying this logic is a sharp distinction between an equilibrium condition, an objective of policy, and a fully operational specification of the monetary policy rule. A target for inflation or for a price level may be an equilibrium condition (ie a state of affairs that one observes ex post). It may be announced as the objective of policy (ie a central bank may choose to announce, say, an inflation or price level target as the medium-term aim of its policy). But it will never constitute an operational version of a strategy, ie a complete description of the bank's decision procedure as an algorithm for action. The latter can only be described in terms of how the bank intends to steer its instruments of policy (ie either a short-term interest rate or some measure of the stock of outside money in circulation) in the face of the various contingencies, as the situation may dictate. And, notably, it is the expectation of a systematic response of such instruments to offequilibrium states which is key in sustaining a virtuous equilibrium. Ultimately, it is the off-equilibrium prescriptions of a policy framework - of any type - which make the framework credible.

The fact that such off-equilibrium prescriptions may involve a distinctive role for monetary aggregates, as information variables and triggers of action, as well as possibly as an instrument of policy alternative to the short-term interest rate, is no accident. Take the example of the liquidity trap. In Krugman's (1998) words: "A liquidity trap involves a type of credibility problem. A monetary expansion that the market expected to be sustained (that is, matched by equiproportional expansions in all future periods) would always work [in lifting the economy off the trap]. If monetary expansion does not work, if there is a liquidity trap, it must be because the public does not expect it to be sustained." The threat to abandon a "moneyless" interest-based policy rule and to switch to a monetary policy rule involving the implementation of a constant rate of growth for the money base - as in Christiano and Rostagno (2001a) - serves precisely this purpose. To make that monetary expansion credible, the central bank needs to provide a detailed operational specification, ie a complete description of the way the central bank will manage its instrument of policy from the time in which the zero lower bound is hit onwards. This operational specification has to make clear that the money supply will have to be increased by enough to render that equilibrium untenable, so that expectations will have to coordinate on a different equilibrium, namely the one dictated by the central bank's objective. ${ }^{42}$

borrowed reserves. In the process, the federal funds rate was free to move to whatever level would be consistent with the money growth objective over time." Mayer's rationale for the switch of focus in policy which occurred in 1979 seems to be consistent with the story told in Christiano and Rostagno (2001). He argues that "monetary policy was focused on steadily reducing inflation, and policymakers were less certain about what increase in nominal and real interest rates would be required to achieve the objective of reducing inflation than they were about the money-inflation relationship." (page 8). This is a rather vivid manner to describe the role of money in 'emergency' situations in which policymakers find alternative money-less rules a less reliable guide for policy adjustment.

41 Other papers rely on the argument that other policies (eg fiscal policy) could be used to stimulate the economy in a deflationary situation.

42 The above notwithstanding, there are other solutions to the instability or indeterminacy problems associated with conventional money-less policy rules, which do not require explicit reliance on monetary aggregates. Money-less rules providing off-equilibrium responses to non-fundamental shocks to expectations are proposed in Svensson and Woodford (2003) within the context of inflation targeting procedures. We refer the reader to footnote 28 for a brief discussion of these rules. 


\title{
4. Robustness and the role of monetary developments in monetary policy rules
}

\author{
Models of monetary policy transmission and their implications for monetary policy \\ rules
}

The preceding section has demonstrated that apparently small deviations from the benchmark New Keynesian macroeconomic model may have profound implications for the design and conduct of monetary policy. At the theoretical level, when conventional monetary policy rules are employed, such deviations from the benchmark model permit indeterminacy and multiplicity of equilibria. In practical terms, this suggests that the mechanical pursuit of Taylor-like rules for monetary policy exposes an economy to the risk of significant instability and substantial deviations from price stability.

The pathologies associated with indeterminacy and multiplicity are not the only implications of varying the assumptions underlying the standard model. Variations to the benchmark New Keynesian model also have implications for the transmission mechanism of monetary policy and thus for the performance of any given monetary policy rule against the loss function described by equation (5). For example, if the assumption that money balances and consumption are weakly separable in the utility function (implicit in the standard New Keynesian model) is relaxed, money balances will enter both the dynamic IS and Phillips curve equations (equations (1) and (2), respectively). Similarly, adopting the Carlstrom and Fuerst (2001a) cash-in-advance timing assumption will result in a role for monetary dynamics in the transmission process. In either case, the performance of monetary policy rules which are designed to preserve price stability around the steady state defined by the linearised relationships analogous to equations (1) to (3) will be affected by how the central bank chooses to vary the shortterm interest rate in response to monetary dynamics. ${ }^{43}$

At this stage, one does not need to stake out a definitive position regarding these underlying and rather technical assumptions about how money balances enter the representative agent's utility function in a dynamic general equilibrium model. Such assumptions are anyway hard to distinguish or verify empirically. One can simply argue that, in pursuing their objective of price stability, monetary policymakers would be ill advised to rely solely on the results of the benchmark New Keynesian model, which appear rather fragile in the face of small (and difficult to reject) variations to the underlying economic structure. In other words, central banks should not ignore completely the insights provided by variations to the benchmark model - especially those which give some role to money - given the long and influential pedigree of money-based analysis in monetary policy design and implementation.

All models are necessarily an abstraction from, and thus a simplification of, reality. Each model emphasises some aspects of the monetary policy transmission process while obscuring others. In some circumstances, the simplifications implied by the benchmark New Keynesian model may provide a better insight into the challenges facing monetary policy. Other circumstances may favour analyses conducted using variants of that benchmark model, which give a more important role to monetary and financial dynamics in the transmission process. Relying on one model to the exclusion of all others appears misguided.

Policymakers therefore need to integrate analysis conducted using a variety of macroeconomic models into a single process for taking monetary policy decisions. This has led to broad acceptance of the view that central banks should base their policy decisions on a suite of models and tools, rather than relying on a single model for policy advice (eg Bank of England (1999), Pill (2001), Selody (2001)).

43 Comparing these variants with the benchmark New Keynesian model, one might argue that two distinct characterisations of monetary policy transmission exist (Engert and Selody (1998)). One tradition (embodied in the work of monetarists, such as Milton Friedman and reflected in the variant models discussed in the main text) views money as central to the determination of the price level. Monetary dynamics therefore play an active role in the transmission mechanism. The other tradition (reflected, for example, in the benchmark model) characterises price dynamics as an outcome of interactions between supply and demand and cost pressures. Within this paradigm, monetary developments do not play an active role in monetary policy transmission, but rather reflect the evolution of the arguments of money demand. Money therefore plays a passive role in price level determination. However, in the latter framework money may be a good indicator of future prices to the extent that it reflects underlying trends in nominal GDP. 
At the very least, the number of variants to the benchmark New Keynesian model used for the analysis of monetary policy reflects substantial continued uncertainty surrounding the monetary policy transmission mechanism. A well designed monetary policy rule or strategy has to confront and overcome this uncertainty.

A substantial literature has considered the conduct of monetary policy in the face of uncertainty (eg ECB-CFS (2000)). With regard to uncertainties about the structure of the economy (typically labelled model or paradigm uncertainty), McCallum (1988) has suggested the following approach. In his view, a well designed monetary policy rule should "perform well" across a set of plausible competing reference models that spans a broad spectrum of model uncertainty. Levin et al (2001) have implemented this approach for New Keynesian models of the US economy. The models investigated by Levin et al are estimated using different data and with somewhat different specifications, but that are all essentially of the benchmark type. ${ }^{44}$

However, following Selody (2001), it is natural to extend McCallum's robustness criterion to encompass analysis under a broader set of variants of the benchmark New Keynesian framework, rather than focusing solely on that benchmark to the exclusion of other models. Therefore, effective monetary policy should perform well in a variety of models of the transmission mechanism, spanning those where money has a structural role in dynamic IS and/or Phillips curve equations and those where it does not (ECB (2000)). ${ }^{45}$

Drawing on the work of Gerdesmeier et al (2002), the remainder of this section investigates these issues. To illustrate our analysis, we use two very simple analytical models, which are described in the Appendix. The benchmark model embodies output gap and Phillips curve equations; the other is a simple $\mathrm{P}^{*}$ framework (Hallman et al (1991)). ${ }^{46}$

As described in Section 2, the available empirical evidence for the euro area suggests that the money stock has a stable relationship with the price level (conditional on developments in other macroeconomic variables) and exhibits leading indicator properties for inflation. In the context of the analysis presented here, it is particularly noteworthy that the $\mathrm{P}^{*}$ model has empirical support in both the euro area (eg Gerlach and Svensson (2002)) and also - albeit more controversially - in the United States (eg Orphanides and Porter (2001)). While certainly not conclusive, such evidence offers some loose empirical support for the plausibility of variants to the benchmark New Keynesian model that give some role to monetary variables in the transmission process.

In the manner of Rudebusch and Svensson (1999), both the benchmark and $\mathrm{P}^{*}$ models are kept extremely simple for expositional purposes. ${ }^{47}$ In particular, we choose to use backward-looking specifications, thereby avoiding many of the problems of determinacy and instability discussed in Section 2. Moreover, by using linearised models around a carefully selected steady state, we limit ourselves to discussion of small perturbations from an equilibrium associated with price stability. We thus focus on how monetary policy should respond to economic shocks (including monetary shocks) in the vicinity of this desired steady state, given uncertainty about the transmission mechanism.

44 More recently, Levin and Williams (2002) have extended their approach to an analysis of forward- and backward-looking Phillips curve models of US monetary policy.

45 One might argue that this approach involves giving preference to monetary policy rules or strategies that avoid bad outcomes (ie instability or indeterminacy of the price level) even in adverse circumstances. This follows Brunner and Meltzer (1968), who - anticipating by some 30 years Hansen and Sargent's (2000) application of robust control theory to monetary policy - advocate monetary targeting on the basis that it provides the least harmful policy framework given the uncertainty surrounding the structure of the transmission mechanism.

46 The specification of the passive money model is a simplified version of the model estimated by Rudebusch and Svensson (1999) (and subsequently employed by Levin and Williams (2002)). The specification of the active money $\mathrm{P}^{*}$ model is that suggested by Svensson (2000).

47 Rudebusch and Svensson (1999) argue that using simple, backward-looking linear models of the transmission mechanism is preferable for expositional purposes because well known optimal control techniques (Sargent (1987)) can be applied straightforwardly, increasing the transparency of the results. 
Following much of the recent academic literature, we characterise monetary policy within our simple analytical framework as a contingent policy rule for short-term nominal interest rates. ${ }^{48}$ Our analysis then proceeds in two steps. First, we discuss the role of monetary developments in optimal interest rate policy rules within the $\mathrm{P}^{*}$ model, which here is seen as representing a variant of the benchmark model where money enters the Phillips curve equation and thus has an active role in the transmission mechanism. The resulting policy rule is compared with the optimal rule derived from the benchmark approach. Second, we discuss how monetary developments should affect interest rate decisions when policymakers entertain both the benchmark model and variants to it, as McCallum's robustness criterion requires.

\section{(ii) Optimal policy rules in the two models - the role of monetary developments}

Adopting the quadratic central bank loss function that has become standard in the academic literature (equation (5)), conventional techniques can be used to derive optimal monetary policy rules for the two models considered here. Given the simplicity of the models, these rules can be expressed as linear functions of the four state variables: inflation, the output gap, and current and lagged values of the real money gap. ${ }^{49}$ These rules are shown in the Appendix. In the main text we summarise some of the simple but important results that follow from this exercise.

Once money enters the structural equations of the transmission mechanism, monetary developments are an argument of the optimal policy rule. Svensson (1997) has shown that optimal monetary policy should respond to the determinants of inflation, not inflation itself. Within the variant to the benchmark model where money enters the Phillips curve, monetary developments are a determinant of price dynamics and thus should influence interest rate decisions that aim to maintain price stability. By the same token, monetary developments do not affect price dynamics in the benchmark model (as already noted in Section 3). Optimal monetary policy for that model will thus be independent of monetary dynamics.

However, even within the variant to the benchmark model where money plays a role in the Phillips curve, the optimal monetary policy cannot be characterised solely as a response to monetary developments. The influence of monetary developments on interest rate decisions should be conditional on developments in other macroeconomic variables. In other words, variables such as the output gap and inflation also enter the optimal monetary policy rule in variants to the benchmark model (when represented by the $\mathrm{P}^{*}$ model). This result has a number of practical implications.

First, as shown by Svensson (2000), even the simple $P^{*}$ framework adopted here does not necessarily provide support for naïve characterisations of monetary targeting. (Intuition would anyway not suggest favouring monetary targeting within the benchmark New Keynesian framework.)

In other words (and adopting the terminology suggested by Svensson (1999a)), even in the context of a simple $\mathrm{P}^{*}$ model, the optimal monetary policy rule is neither a simple money-based instrument rule of the form:

$i_{t}=\varphi\left[\left(\ln \mathbf{M}_{t}-\ln \mathbf{M}_{t-1}\right)-k\right]$

nor an intermediate monetary targeting rule defined (implicitly) as the solution to the following problem:

minimise $\quad E_{0} \sum\left[\left(\ln \mathbf{M}_{t}-\ln \mathbf{M}_{t-1}\right)-k\right]^{2}$

subject to the constraints implied by the structure of the underlying economic model..$^{50}$

48 Of course, as a practical matter, we would not advocate mechanical pursuit of such a policy rule by central banks, since the exercise of informed judgment is a crucial component of any policy regime. Nonetheless, analytical exercises involving monetary policy rules constitute a useful reference point for policy analysis, giving the basis for a systematic (if not rulebound) policymaking process (see ECB (2001c)).

49 As in Gerlach and Svensson (2002), the real money gap is defined as the difference between the observed real money stock and the real money stock consistent with real output at potential and income velocity at its long-run equilibrium level.

$50 k$ is a benchmark rate of monetary growth, for example that consistent with the maintenance of price stability over the medium term. 
Indeed, as shown in the Appendix, even in the simple models considered here, the performance of pure money-based rules such as equations (7) and (8) appears quite poor. ${ }^{51}$ Pure money-based rules do not come close to mimicking the optimal policy rule in either the benchmark model or variants to it.

Second, the bivariate relationship between monetary dynamics (in particular, monetary growth) and optimal monetary policy (captured by the level of short-term nominal interest rates) is complicated by developments in other variables, and is therefore likely to be complex. On this basis, one should not anticipate a simple linear unconditional relationship between interest rates and monetary growth. Table 4 (in the Appendix) shows the bivariate correlations between inflation, monetary growth and interest rate in stochastic simulations of the two models, assuming the central bank follows the associated optimal policy rule. The bivariate correlations between monetary growth and interest rates are quite low, reflecting the complex and conditional nature of this relationship. ${ }^{52}$

Finally, the analysis in the Appendix demonstrates that the relationship between optimal interest rate decisions and monetary developments is shock-specific. In both simple models of monetary transmission entertained here, the bivariate relationship between monetary growth and interest rates depends on whether there is a demand shock, a supply shock or a monetary shock. In response to some shocks, the optimal monetary policy response in the face of rapid monetary growth may be a large immediate rise in interest rates. In response to other shocks, the optimal monetary policy response in the face of rapid monetary growth may be smaller and more gradual. Indeed, in some contexts, faster monetary growth may point to no interest rate change or even an interest rate cut. ${ }^{53}$ Again, this suggests that interest rate changes should not be mechanically linked to monetary growth and that the bivariate relationship between interest rate changes and monetary dynamics may be complex if the optimal policy rule is being followed.

Another implication of the shock-specific behaviour of money is that monetary developments can help identify the nature of shocks and thus prompt an appropriate interest rate response. This is a necessary component of optimal policy in the $\mathrm{P}^{*}$ model, where monetary shocks have an impact on price dynamics. However, even in the benchmark New Keynesian model where money plays no role in the transmission process, cross correlations in the dynamic responses of money and other macroeconomic variables imply that monetary dynamics can help to identify the nature of the shocks. They can thus provide information useful to policymakers who would optimally respond in a shockspecific manner. Money may therefore prove to be a useful indicator even in the benchmark New Keynesian framework. This is the essence of the Coenen et al (2001) result reported in Section 2.

\section{(iii) Formulating rules that perform well in both paradigms}

Gerdesmeier et al (2002) consider the design of monetary policy rules where, because of uncertainty about which model or variant is most realistic or relevant, policymakers entertain a variety of models of monetary policy transmission. As one would expect, they show that monetary developments should influence monetary policy decisions when money plays an active role in the monetary transmission mechanism within at least one of the models being considered.

This conclusion is intuitive. However, Gerdesmeier et al (2002) obtain a number of other, less obvious results. Within their framework, they show that monetary developments play an important role in interest rate decisions (in the sense that the coefficient on the real money gap in the favoured monetary policy rule is large) even when the weight accorded to the variant of the benchmark model (captured by the $\mathrm{P}^{*}$ specification) is relatively low. The intuition behind this result is as follows. Gerdesmeier et al (2002) minimise a weighted average of the losses in the two models. Ignoring monetary developments in the $\mathrm{P}^{*}$ model may be costly, because a crucial determinant of price dynamics is being ignored. At the same time, allowing a role for monetary dynamics in the benchmark

51 Given the trivial nature of the models, it is hard to assign an economic meaning to the values of the loss function in terms of some more fundamental welfare measure. In other words, their ad hoc nature means that micro-founded welfare criteria are not available.

52 Interestingly, this correlation is even lower in the active money $\mathrm{P}^{*}$ model than in the passive money framework.

53 This is, of course, simply an implication of the need to condition the interest rate decision on other variables in addition to money. 
model may be relatively benign. Even in the benchmark model, monetary dynamics are associated with developments in the output gap, inflation and interest rates, which are themselves determinants of inflation within that model. Monetary developments may therefore capture information in other, policyrelevant variables ${ }^{54}$ As a result, the costs of ignoring money in the $\mathrm{P}^{\star}$ variant to the benchmark model may rise more rapidly than the benefits of ignoring money in the benchmark framework. This leads to a relatively prominent role for money in a policy rule that addresses model uncertainty across the $\mathrm{P}^{*}$ and benchmark specifications.

Gerdesmeier et al (2002) also show that their favoured monetary policy rule implies larger responses to all state variables (including the real money gap, the monetary argument in their policy rule) than would be implied by alternative approaches, such as averaging the optimal rules from the two models (ie analysing the benchmark and variant models without reference to one another) or deriving an optimal rule from a hybrid framework that averages the two models (ie obscuring the distinction between the benchmark and its variant). ${ }^{55}$

Although the conditional response of interest rates to monetary developments may be large, this does not imply that the unconditional volatility of interest rates under the policy rules analysed by Gerdesmeier et al (2002) will be higher than for other policy regimes. As discussed above, interest rates also respond to variables other than money. In practice, developments in money may therefore be offset by developments in other arguments of the policy rule, such as inflation and/or the output gap, resulting in modest unconditional interest rate volatility.

The Gerdesmeier et al (2002) paper thus leads to three conclusions. First, once variants to the benchmark New Keynesian model are entertained, monetary developments may influence monetary policy decisions. Second, the role accorded to monetary dynamics in formulating interest rate decisions may be relatively large, even if the weight accorded to the variant model that emphasises the role of money is modest. Third, on occasion arguments of the monetary policy rule will point in different directions. The output gap may suggest a rate increase, while monetary dynamics suggest a rate cut. This should not be seen as a shortcoming of the approach. Indeed, the role of the monetary policy rule is precisely to provide a framework for reconciling and combining the information in various indicators into a single robust interest rate decision.

\section{Concluding remarks}

Much recent academic literature on monetary policy has suggested that monetary aggregates should not play a large role in monetary policy decisions. Within the so-called new neoclassical synthesis, monetary developments are not seen as playing an active role in the transmission mechanism of monetary policy. Monetary policy rules advocated by adherents of these models are often moneyless they suggest that central banks can neglect or even ignore monetary developments when taking interest rate decisions. Moreover, many prominent empirical studies, in particular for the United States, have concluded that the demand for money is unstable in both long and short runs and that monetary developments largely constitute "noise" which policymakers would do well to ignore.

This paper has challenged these very strong - and, in our view, erroneous - conclusions.

54 For example, the real money gap is positively related to the output gap. If interest rates rise in response to a positive money gap (as the $\mathrm{P}^{*}$ model would require), they will implicitly rise in response to an output gap (as the passive money framework would require). The loss associated with responding to the money gap in the passive money paradigm therefore may be modest.

55 This result runs counter to the conclusions of Brainard (1967) inter alia, which suggest that uncertainty about the structure of the transmission mechanism should lead to attenuated monetary policy responses. Gerdesmeier et al (2002) offer the following intuition. The Brainard result follows from the possibility that structural uncertainty renders inflation uncontrollable using an interest rate instrument. In such circumstances, changing interest rates would simply destabilise other variables such as the output gap without helping to maintain price stability. If such a scenario is possible, monetary policy responses will be attenuated to avoid the destabilising impact of such a policy. However, in the Gerdesmeier et al (2002) framework, controllability is possible in both the benchmark model and its variant. The issue is not whether the system is controllable, but rather the channels through which control is exercised. In this environment, monetary policy responses are stronger than in the Brainard framework. 
On empirical grounds, we survey a large literature which supports the view that money both has a stable relationship with prices in the euro area and exhibits leading indicator properties for future price developments, at least in the euro area.

On conceptual grounds, we note that monetary policy regimes which neglect monetary developments are prone to expectational instability - a practical, as well as theoretical, problem, which may lead to the maintenance of price stability being threatened. Broadly speaking, these results follow from the observation that monetary policy regimes which ignore money may lack a nominal anchor.

On empirical and practical grounds, we suggest that monetary developments contain information about the state of the economy which - regardless of whether money plays an active role in the transmission mechanism of monetary policy - should be integrated into the policymaking process. Of course, in models where money does play an "active" role, monetary dynamics necessarily enter optimal policy rules. 


\section{Appendix: \\ Model uncertainty and monetary policy rules}

\section{(a) The output gap model}

In its simplest form, the "output gap model" (OGM) (representative of the benchmark view of monetary policy transmission) can be presented as:

$$
\begin{aligned}
& y_{t}=\lambda y_{t-1}-\delta\left(i_{t-1}-E_{t-1} \pi_{t}\right)+\varepsilon_{s, t} \\
& \pi_{t}=\pi_{t-1}-\beta\left(y_{t-1}-y_{t-1}^{*}\right)+\varepsilon_{s, t}
\end{aligned}
$$

where $y$ is the output gap, $i$ is the short-term nominal interest rate under the control of the central bank, $\pi$ is inflation and $\varepsilon_{d}$ and $\varepsilon_{s}$ are demand and supply shocks, respectively. For notational simplicity, the variables are de-meaned and de-trended, such that potential output is zero (see Rudebusch and Svensson (1999)).

To facilitate comparisons with the $\mathrm{P}^{*}$ model discussed below, a money demand equation is appended to the basic OGM. The money demand equation is "appended" in the sense that price and output dynamics are fully determined by equations (9) and (10): this is why the OGM represents the benchmark view of monetary transmission. This money demand equation has a standard error correction specification, namely:

$$
\Delta(m-p)_{t}=\phi \Delta(m-p)_{t-1}-\vartheta\left((m-p)_{t-1}-y_{t-1}+\gamma i_{t-1}\right)+\varepsilon_{m d, t}
$$

\section{(b) The $\mathbf{P}^{\star}$ model}

The $\mathrm{P}^{*}$ model (representative of variants to the benchmark view of monetary policy transmission) can be summarised by the following system of equations (where the notation is the same as above, with $i^{*}$ the nominal short-term interest rate holding in steady state equilibrium with price stability, normalised to zero) (see Hallman et al (1991), Svensson (2000)):

$$
\begin{aligned}
& y_{t}=\lambda y_{t-1}-\delta\left(i_{t-1}-E_{t-1} \pi_{t}\right)+\varepsilon_{s, t} \\
& \Delta(m-p)_{t}=\phi \Delta(m-p)_{t-1}-\vartheta\left((m-p)_{t-1}-y_{t-1}+\gamma i_{t-1}\right)+\varepsilon_{m d, t} \\
& \pi_{t}=(1-\omega) \pi_{t-1}+\omega \Delta p_{t-1}^{*}-\mu\left(p_{t-1}-p_{t-1}^{*}\right)+\varepsilon_{s, t} \\
& p_{t}^{*}=m_{t}-y_{t}^{*}-\lambda i^{*}=m_{t}
\end{aligned}
$$

\section{(c) Central bank preferences}

Consistent with the academic literature, the objectives of the central bank are summarised by the loss function (equation (5)), which is used here for illustrative purposes. Note that this loss function assumes a steady state rate of inflation of zero, which - in the context of this framework - corresponds to the central bank's definition of price stability.

\section{(d) Analysis}

Using conventional techniques (as discussed, for example, in Rudebusch and Svensson (1999)), each model can be solved to find the "optimal monetary policy rule" which minimises the loss function (equation (5)). As discussed in the main text, this rule (and the results it obtains) can then be 
compared with simple money-based rules, such as those defined by equations (7) and (8). ${ }^{56}$ This exercise is presented in Table 3.

Table 3

Performance of optimal and money-based rules in the two models

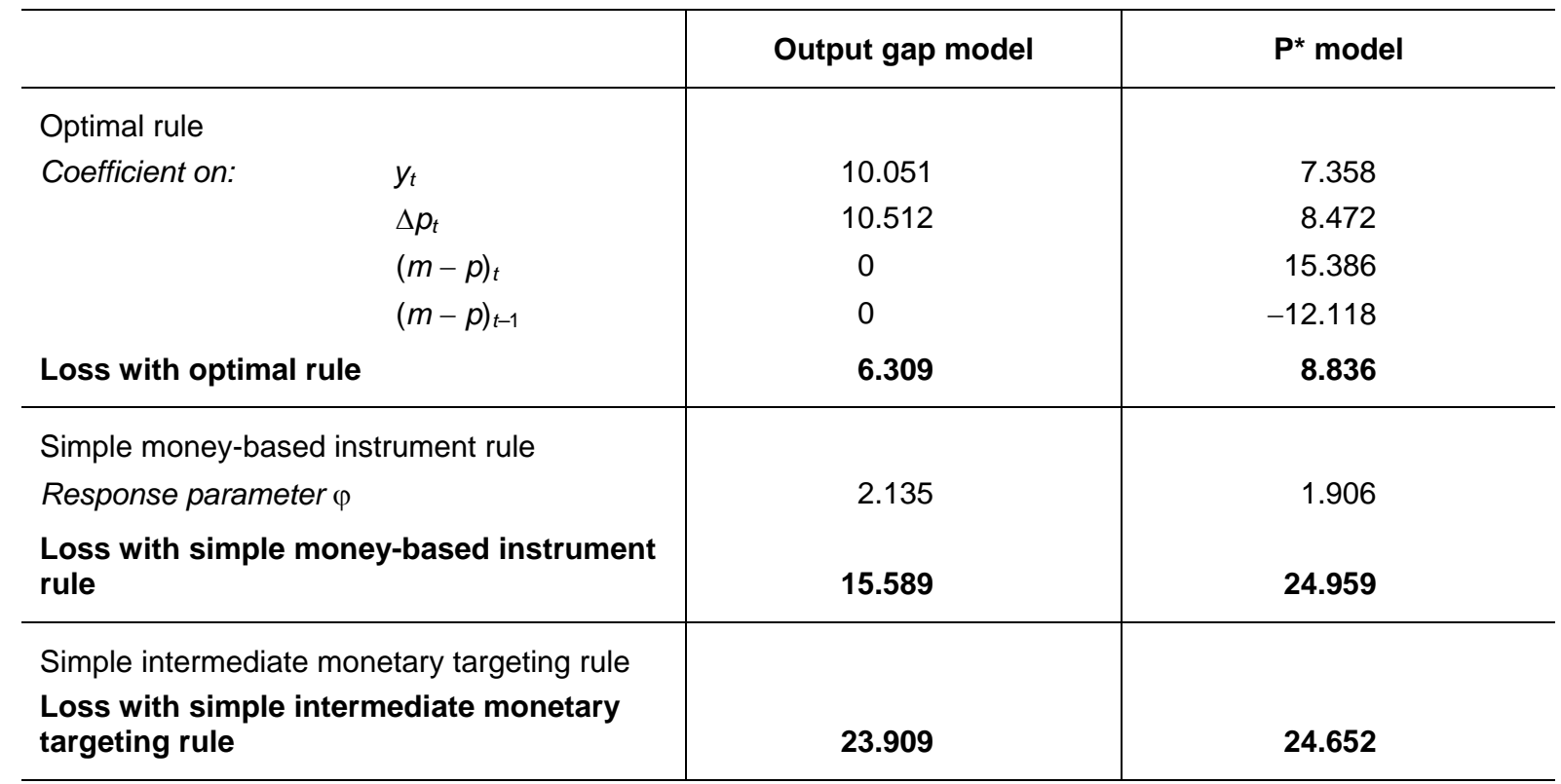

Note: Because of the de-meaning and de-trending of all variables, all steady states have been normalised to zero.

Table 4

Bivariate correlations in simulations of the two models under optimal rules

\begin{tabular}{l|c|c|c}
\hline & Inflation & Monetary growth & Interest rates \\
\hline $\begin{array}{l}\text { (a) Output gap model } \\
\text { Inflation }\end{array}$ & 1 & & \\
Monetary growth & 0.77 & 0.35 & 1 \\
Interest rates & 0.40 & & \\
\hline (b) $P^{*}$ model & 1 & & \\
Inflation & 0.86 & 1 & 1 \\
Monetary growth & 0.16 & 0.22 & 1 \\
Interest rates & & & \\
\hline
\end{tabular}

56 For the simple money-based instrument rule (equation (1)), the response parameter $\varphi$ is chosen so as to minimise the central bank's loss function described by equation (5). 
Table 4 shows the bivariate correlations between short-term nominal interest rates, inflation and monetary growth in the two simple models, under the assumption that the optimal rule described in Table 3 is followed. These results are discussed in the main text. Note that, counter to intuition, the contemporaneous correlation between optimal interest rate changes and money growth is higher in the benchmark model (rather than the variant $\mathrm{P}^{*}$ model where money enters the Phillips curve and thus plays an active role in monetary transmission).

Table 5 describes the policy rule that minimises the average central bank loss over the two models presented above and permits comparison with the optimal rule for each of the two underlying models. This rule is one variant of the monetary policy rules analysed in Gerdesmeier et al (2002) that attempt to address the problem of model uncertainty, ie the need to arrive at a single interest rate decision on the basis of analysis in both the benchmark model and in the variant of it. As noted in the main text, the response of interest rates to monetary developments (ie the response coefficients on the money gap in the policy rule) is large. Moreover, these coefficients are greater than the average of the two corresponding coefficients in the individual underlying models. The intuition behind these results is discussed in the main text.

Table 5

Coefficients and performance of rule that minimises average central bank loss over the two paradigms

\begin{tabular}{l|c|c|c}
\hline & $\begin{array}{c}\text { Bayesian rule } \\
\text { weighting loss } \\
\text { functions }(\boldsymbol{q}=\mathbf{0 . 5})\end{array}$ & OGM optimal rule & $\mathbf{P}^{\star}$ optimal rule \\
\hline $\begin{array}{l}\text { Coefficient in weighted } \\
\text { rule on: }\end{array}$ & 9.572 & 10.051 & 7.358 \\
$\left(y-y^{*}\right)_{t}$ & 9.481 & 10.512 & 8.472 \\
$\Delta p_{t}$ & 9.525 & 0 & 15.386 \\
$(m-p)_{t}$ & -8.190 & 0 & -12.118 \\
$(m-p)_{t-1}$ & 7.096 & 6.309 & 9.210 \\
\hline Loss in OGM & 9.456 & 12.673 & 8.836 \\
Loss in $P^{*}$ model & 8.276 & 9.491 & 9.023 \\
\hline Mean loss & 9.456 & 12.673 & 9.210 \\
\hline Maximum loss &
\end{tabular}

Note: The rule described above minimises the average central bank loss over the two paradigms (summarised by the two models), ie $\min L=0.5 \times L_{O G}+0.5 \times L_{P^{*}}$.

The parameter calibrations used to undertake the exercises reported in this Appendix are shown in Table 6.

In synthesis, in both of the models introduced in this Appendix, the adoption of a monetary policy rule that preserves price stability ensures that monetary growth will fluctuate around its steady state rate (ie M3 growth oscillates around the reference value). This is a direct implication of the observation that the optimal policy rule in both models will render the economic system stable if it is to preserve price stability. Yet if the underlying monetary policy rule adopted by the central bank does not preserve price 
stability, ${ }^{57}$ then monetary growth diverges from the steady state (ie the reference value) in both models.

Table 6

Calibrated values for the model parameters

\begin{tabular}{|c|c|c|}
\hline Parameter & Calibrated value & Economic interpretation \\
\hline$\lambda$ & 0.9 & Output persistence. \\
\hline$\delta$ & 0.1 & Real interest rate elasticity of aggregate demand. \\
\hline$\beta$ & 0.1 & Sensitivity of inflation to the output gap. \\
\hline$\phi$ & 0.6 & Persistence of real monetary growth. \\
\hline v & 0.1 & Error correction coefficient in money demand equation. \\
\hline$\gamma$ & 0.25 & Long-run interest rate elasticity of money demand. \\
\hline$\omega$ & 0.5 & Weight on lagged inflation in $\mathrm{P}^{*}$ inflation equation. \\
\hline$\mu$ & 0.2 & Error correction coefficient in $\mathrm{P}^{*}$ inflation equation. \\
\hline$\sum_{\mathrm{OG}}=\sum_{\mathrm{P}^{*}}$ & {$\left[\begin{array}{llll}1 & 0 & 0 & 0 \\
0 & 1 & 0 & 0 \\
0 & 0 & 1 & 0 \\
0 & 0 & 0 & 0\end{array}\right]$} & $\begin{array}{l}\text { Covariance matrix of the structural economic (demand, supply and } \\
\text { money) shocks. (For simplicity, a diagonal matrix with unit variances } \\
\text { is assumed for both models.) }\end{array}$ \\
\hline$\psi$ & 0.5 & $\begin{array}{l}\text { Relative weight on inflation variance in the central bank's loss } \\
\text { function. }\end{array}$ \\
\hline
\end{tabular}

\section{References}

Bank of England (1999): Economic models at the Bank of England, London.

Benhabib, J, S Schmitt-Grohé and M Uribe (2001a): "The perils of Taylor rules", Journal of Economic Theory, vol 96, no 1, pp 40-69.

(2001b): "Avoiding liquidity traps", Journal of Political Economy, forthcoming.

(2001c): Chaotic interest rate rules, mimeo.

Bernanke, B S and M Woodford (1997): "Inflation forecasts and monetary policy", Journal of Money, Credit and Banking, vol 29.

Bordo, M and O Jeanne (2002): "Boom-busts in asset prices, economic instability and monetary policy", NBER Working Paper, no w8966, May.

Borio, C and P Lowe (2002): "Asset prices, financial and monetary stability: exploring the nexus", BIS Working Papers, no 114, July.

Brainard, W (1967): "Uncertainty and the effectiveness of policy", American Economic Review, vol 57, pp 411-25.

57 In the output gap model, it is sufficient to choose a monetary policy rule with a coefficient less than unity on inflation, such that the real interest rate does not rise in response to an inflationary shock (see Clarida et al (1999)). In other words, violating the Taylor principle is sufficient to induce instability. This condition is not sufficient in the $\mathrm{P}^{*}$ model: a rule that preserves price stability may have a coefficient less than unity on inflation in this context. 
Brand, C and N Cassola (2000): "A money demand system for euro area M3", ECB Working Paper, no 39.

Brand, C, D Gerdesmeier and B Roffia (2002): "The derivation of the reference value for monetary growth", ECB Occasional Paper, no 2.

Bruggeman, A, P Donati and A Warne (2003): "Is the demand for euro area M3 stable?", mimeo.

Brunner, K and A H Meltzer (1968): "Liquidity traps for money, bank credit, and interest rates", Journal of Political Economy, vol 76, no 1, pp 1-37.

Bullard, J and K Mitra (2000): "Learning about monetary policy rules", Federal Reserve Bank of St Louis Working Paper, no 2000-001b.

Calza, A, D Gerdesmeier and J Levy (2001): "Euro area money demand: measuring the opportunity costs appropriately", IMF Working Paper, no 01/179.

Carlstrom, C and T Fuerst (2001a): "Timing and real indeterminacy in monetary models", Journal of Monetary Economics, vol 47.

(2001b): Learning and the central bank, mimeo.

Christiano, L and C J Gust (1999): Comment on A Levin, V Wieland and J C Williams, "Robustness of simple monetary policy rules under model uncertainty", in J B Taylor (ed), Monetary policy rules, Chicago: University of Chicago Press.

Christiano, L and M Rostagno (2001a): "Money growth monitoring and the Taylor rule", NBER Working Paper, no 8539.

(2001b): Money growth monitoring in a limited participation model, mimeo.

Christiano, L, M Eichenbaum and C Evans (1997): "Sticky price and limited participation models of money: a comparison”, European Economic Review, vol 41, pp 1201-49.

(2001): Nominal rigidities and the dynamic effects of a shock to monetary policy, mimeo.

Clarida, R, J Galí and M Gertler (1999): "The science of monetary policy: a New Keynesian perspective", Journal of Economic Literature, vol 37, no 4, pp 1661-721.

(2000): "Monetary policy rules and macroeconomic stability: evidence and some theory", The Quarterly Journal of Economics, February, pp 147-80.

Coenen, G and J-L Vega (1999): "The demand for M3 in the euro area”, ECB Working Paper, no 6.

Coenen, G, A Levin and V Wieland (2001): "Data uncertainty and the role of money as an information variable for monetary policy", ECB Working Paper, no 84.

Cristadoro, R, M Forni, L Reichlin and G Veronese (2001): "A core inflation index for the euro area", Banca d'Italia, Temi di discussione, no 435.

European Central Bank (1999a): "The stability-oriented monetary policy strategy of the Eurosystem", ECB Monthly Bulletin, January, pp 39-50.

(1999b): "Euro area monetary aggregates and their role in the Eurosystem's monetary policy strategy", ECB Monthly Bulletin, February, pp 29-46.

(2000): "The two pillars of the ECB's monetary policy strategy", ECB Monthly Bulletin, November, pp 37-48.

(2001a): "Framework and tools of monetary analysis", ECB Monthly Bulletin, May, pp 41-58.

(2001b): "The reference value for monetary growth", ECB Monthly Bulletin, December, pp 11-13.

(2001c): "Issues related to monetary policy rules", ECB Monthly Bulletin, October, pp 37-50.

European Central Bank - Center for Financial Studies (2000): Monetary policy and uncertainty, Frankfurt.

Engert, W and J Selody (1998): "Uncertainty and multiple paradigms", Bank of Canada Working Paper, no 98-7. 
Engle, R F and C W J Granger (1987): "Cointegration and error correction: representation, estimation and testing", Econometrica, vol 50, pp 987-1007.

Evans, G W and S Honkapohja (2001): Expectations and the stability problem for optimal monetary policies, mimeo.

Friedman, M and A Schwartz (1963): A monetary history of the United States, 1867-1960, Princeton University Press, Princeton, New Jersey.

Galí, J (2001): "Money policy in the early years of EMU", paper prepared for the conference "The functioning of EMU: the challenges of the early years", organised by the European Commission, Brussels, 21-22 March.

Gerlach, S and L E O Svensson (2002): "Money and inflation in the euro area: a case for monetary indicators?", CEPR Working Paper, no 3392.

Gerdesmeier, D, R Motto and H Pill (2002): "Paradigm uncertainty and the role of monetary developments in monetary policy rules", available at: www.ecb.int/events/conf/other/mprules.htm.

Goodfriend, M and R G King (1997): "The new neoclassical synthesis and the role of monetary policy", in B Bernanke and J Rotemberg (eds), NBER Macroeconomics Annual 1997, Cambridge, MA: MIT Press.

Gottschalk, J F, M Rico and W Van Zandweghe (1999): "Money as an indicator in the euro zone", Kiel Working Paper, no 984.

Hallman, J J, R D Porter and D H Small (1991): "Is the price level tied to the M2 monetary aggregate in the long run?", American Economic Review, vol 81, pp 841-58.

Hansen, L P and T J Sargent (2000): Wanting robustness in macroeconomics, mimeo, Stanford University.

Hume, D (1752): "Of money", reprinted in Writings on economics, E Rotwein (ed) (1970), Madison: University of Wisconsin Press.

Issing, O (2002): "Monetary policy in a changing environment", contribution to the symposium on "Rethinking stabilization policy", hosted by the Federal Reserve Bank of Kansas City, Jackson Hole, 30 August 2002.

Issing, O, V Gaspar, I Angeloni and O Tristani (2001): Monetary policy in the euro area: strategy and decision-making at the European Central Bank, Cambridge University Press.

Jensen, $\mathrm{H}$ (2002a): "Monetary policy frameworks and real equilibrium determinacy," mimeo, University of Copenhagen.

Jensen, H (2002b): "Targeting nominal income growth or inflation?," American Economic Review 92(4), September.

Johansen, S and K Juselius (1990): "Maximum likelihood estimation and inference on cointegration with application to the demand for money", Oxford Bulletin of Economics and Statistics, vol 52, pp 162210.

Kerr, W and R King (1996): "Limits on interest rate rules in the IS-LM model", Federal Reserve Bank of Richmond Economic Quarterly, Spring.

King, M A (2002): "No money, no inflation - the role of money in the economy", Bank of England Quarterly Bulletin, Summer, pp 162-77.

Krugman, P (1998): "It's baaack! Japan's slump and the return of the liquidity trap", Brookings Papers on Economic Activity, vol 2, pp 137-87.

Leeper, E (1991): "Equilibria under 'active' and 'passive' monetary and fiscal policies", Journal of Monetary Economics, vol 27, pp 129-47.

Levin, A and J Williams (2002): Robust monetary policy with competing reference models, presentation to the NBER Summer Institute.

Levin, A, V Wieland and J Williams (2001): "The performance of forecast-based monetary policy rules under model uncertainty", ECB Working Paper, no 68.

Loyo, E (1999): Tight money paradox on the loose: a fiscalist hyperinflation, mimeo. 
Masuch, K, H Pill and C Willeke (2001): "Framework and tools of monetary analysis", in H-J Klöckers and C Willeke (eds), Monetary analysis: tools and applications, European Central Bank.

Mayer, L (2001): "Does money matters?" The Federal Reserve Bank of Saint Louis Review, September/October.

McCallum, B (1981): "Price level determinacy with an interest rate policy rule and rational expectations", Journal of Monetary Economics, vol 8.

(1988): "Robustness properties of a rule for monetary policy", Carnegie-Rochester Series on Public Policy, vol 29, pp 173-209.

(2000): "Alternative monetary policy rules: a comparison with historical settings for the United States, the United Kingdom and Japan", NBER Working Paper, no w7725, June.

(2001): "Monetary policy analysis in models without money", NBER Working Paper, no 8174.

McCandless, G T and W E Weber (1995): "Some monetary facts", Federal Reserve Bank of Minneapolis Quarterly Review, vol 19, pp 2-11.

Meyer, L H (2001): "Does money matter?", the 2001 Homer Jones Memorial Lecture, Washington University, St Louis, Missouri, 28 March 2001.

Nelson, E (2002): "Direct effects of base money on aggregate demand: theory and evidence", Journal of Monetary Economics, vol 49, pp 687-708.

Nicoletti-Altimari, S (2001): “Does money lead inflation in the euro area?”, ECB Working Paper, no 63.

Orphanides, A (2000): “The quest for prosperity without inflation”, ECB Working Paper, no 15.

Orphanides, A and R Porter (2001): "Money and inflation: the role of information regarding the determinants of M2 behaviour", in H-J Klöckers and C Willeke (eds), Monetary analysis: tools and applications, European Central Bank.

Pill, H (2001): "Monetary analysis: tools and applications", in H-J Klöckers and C Willeke (eds), Monetary analysis: tools and applications, European Central Bank.

Rudebusch, G and L E O Svensson (1999): "Policy rules for inflation targeting", in J B Taylor (ed), Monetary policy rules, University of Chicago Press.

Sargent, T J (1987): Dynamic macroeconomic theory, Harvard University Press.

Sargent, T J and N Wallace (1975): "Rational expectations, the optimal monetary instrument and the optimal money supply rule", Journal of Political Economy, vol 3.

Selody, J (2001): "Uncertainty and multiple perspectives", in H-J Klöckers and C Willeke (eds), Monetary analysis: tools and applications, European Central Bank.

Södertröm, U (2001): "Targeting inflation with a prominent role for money", Sveriges Riksbank Working Paper, no 123.

Stock, J and M Watson (1999): "Forecasting inflation", Journal of Monetary Economics, vol 44, pp 293335.

Stracca, L (2000): "The functional form of the demand for euro area M1", ECB Working Paper, no 51.

(2001): "Does liquidity matter? Properties of a synthetic Divisia monetary aggregate in the euro area", ECB Working Paper, no 79.

Svensson, L E O (1997): "Inflation forecast targeting: implementing and monitoring inflation targets", European Economic Review, vol 41, pp 1111-46. pp 607-54.

(1999a): "Inflation targeting as a monetary policy rule", Journal of Monetary Economics, vol 43,

(1999b): "How should monetary policy be conducted in an era of price stability?", NBER Working Paper, no 7516.

(2000): "Does the $\mathrm{P}^{*}$ model provide any rationale for monetary targeting?", German Economic Review, vol 1, pp 69-81. 
(2001): "The zero bound in an open economy: a foolproof way of escaping from a liquidity trap", Monetary and Economic Studies, pp 277-321, February.

Svensson, L E O and M Woodford (2003): Implementing optimal policy through inflation-forecast targeting, mimeo.

Taylor, J B (1993): "Discretion versus policy rules in practice", Carnegie-Rochester Series on Public Policy, vol 29, pp 173-209.

(1999): Monetary policy rules, Chicago: University of Chicago Press.

Trecroci, C and J-L Vega (2000): "The information content of M3 for future inflation", ECB Working Paper, no 33.

Vestin, D (1999): "Price level targeting versus inflation targeting in a forward-looking model", mimeo, available at http://vestin.bei.t-online.de/html/price.html.

Woodford, M (1997): "Control of the public debt: a requirement for price stability?", in G Calvo and M King (eds), The Debt Burden and Monetary Policy, London: Macmillan.

— (1999): "Optimal monetary policy inertia", NBER Working Paper, no 7261.

(2000a): "Fiscal requirements for price stability", the 2000 Money Credit and Banking Lecture, presented at Ohio State University on 1 May 2000.

_ (2000b): "Pitfalls of forward-looking monetary policy," American Economic Review 90(2), May.

(2002): "Interest and prices: foundations of a theory of monetary policy", Princeton University Press, forthcoming. 